\title{
NMR Study of Intercalates and Grafted Organic Derivatives of $\mathrm{H}_{2} \mathrm{La}_{2} \mathrm{Ti}_{3} \mathrm{O}_{10}$
}

\author{
Marina G. Shelyapina ${ }^{1, *}$, Oleg I. Silyukov ${ }^{2}$, Irina P. Lushpinskaia ${ }^{1,3}$, Sergey A. Kurnosenko ${ }^{2}$, \\ Anton S. Mazur ${ }^{3}$, Ilya G. Shenderovich ${ }^{4}$ (D) and Irina A. Zvereva ${ }^{2}$ \\ 1 Department of Nuclear Physics Research Methods, Saint-Petersburg State University, \\ 7/9 Universitetskaya nab., 199034 St. Petersburg, Russia; ira.lushpinskaya.94@mail.ru \\ 2 Institute of Chemistry, Saint-Petersburg State University, 7/9 Universitetskaya nab., \\ 199034 St. Petersburg, Russia; silyukov@spbu.ru (O.I.S.); st040572@student.spbu.ru (S.A.K.); \\ irina.zvereva@spbu.ru (I.A.Z.) \\ 3 Magnetic Resonance Research Center, Saint-Petersburg State University, 7/9 Universitetskaya nab., \\ 199034 St. Petersburg, Russia; a.mazur@spbu.ru \\ 4 Faculty of Chemistry and Pharmacy, University of Regensburg, Universitätsstr. 31, \\ 93040 Regensburg, Germany; Ilya.Shenderovich@chemie.uni-regensburg.de \\ * Correspondence: marina.shelyapina@spbu.ru
}

Academic Editors: Eugene A. Goodilin and Alexey Tarasov

Received: 14 October 2020; Accepted: 8 November 2020; Published: 10 November 2020

\begin{abstract}
The protonated perovskite-like titanate $\mathrm{H}_{2} \mathrm{La}_{2} \mathrm{Ti}_{3} \mathrm{O}_{10}$ has been used to produce organic-inorganic hybrids with simple organic molecules: methylamine, methanol, monoethanolamine, and $n$-butylamine. The optimal pathways for the preparation of such hybrids are summarized. Solid-state NMR, combined with thermal analysis, Raman, and IR spectroscopy, has been applied to determine the bonding type in the obtained organic-inorganic hybrids. It has been found that, in the methanolic hybrid, the organic residues are covalently bound to the inorganic matrix. In contrast, in the methylamine and $n$-butylamine hybrids, the organic molecules are intercalated into the inorganic matrix in cationic forms. The structure of the monoethanolamine hybrid is composite and includes both the covalently bound and intercalated organic species.
\end{abstract}

Keywords: layered perovskite-like oxides; organic-inorganic hybrid; intercalation; grafting; NMR

\section{Introduction}

Organic-inorganic hybrid composites are now widely used in the development of innovative functional materials for photovoltaics, photocatalysis, optoelectronics, and pharmaceutics $[1,2]$. One of the ways to obtain such hybrid materials is the incorporation of organic molecules into an inorganic matrix; in particular, this approach is often implemented in the case of layered inorganic compounds [3]. Among other inorganic matrices, layered perovskite-like oxides look like one of the most promising, as they themselves exhibit photocatalytic activity [4] that can be enhanced through various modifications [5]. Ion-exchangeable-layered perovskite-like oxides $\mathrm{M}_{m}\left(\mathrm{~A}_{n-1} \mathrm{~B}_{n} \mathrm{O}_{3 n+1}\right)$ are solid crystalline substances possessing a block-type structure in which perovskite slabs $\left(\mathrm{A}_{n-1} \mathrm{~B}_{n} \mathrm{O}_{3 n+1}\right)$ with the thickness of $n \mathrm{BO}_{6}$ octahedra alternate with interlayer spaces containing alkali cations $\mathrm{M}$ [6]. Such perovskite-like oxides demonstrate relatively high chemical reactivity in ion exchange $[7,8]$, intercalation [9,10], and exfoliation processes [11-14]; some of them have practically significant photocatalytic [5,15-22], electrophysical [23,24], and luminescent [25] properties.

A treatment of ion-exchangeable perovskite-like oxides with acids cause a replacement of interlayer alkali cations with protons, giving so-called protonated forms. In this form, these perovskite-like oxides are able to react with some organic compounds, forming inorganic-organic hybrids—substances 
consisting of chemically bonded inorganic and organic parts, in which the inorganic one serves as a spatial frame [26]. According to the type of bonding between the inorganic and organic parts, there are two ways of hybrid formation: intercalation and grafting [27]. Intercalation is a reversible noncovalent introduction of organic bases (primarily amines) into the interlayer space by the acid-base or ion-exchange mechanism [28]. Covalent inorganic-organic hybrids can be produced by grafting reactions-the condensation of the protonated forms and appropriate organic substances (alcohols [29], alkoxysilanes [30], carbohydrates [31], carboxylic, and organophosphorus acids [32]), which is accompanied by the formation of covalent bonds $\mathrm{B}-\mathrm{O}-\mathrm{C}(\mathrm{B}=\mathrm{Ti}, \mathrm{Nb}$, Ta, etc.). These hybrids are of high interest for study due to the possibility of combining and fine-tuning useful properties of the inorganic and organic parts in one material $[33,34]$. The properties of hybrid materials are governed beside others by the type of chemical bonding between the organic and inorganic parts. Intercalated hybrids not only combine the physicochemical properties of both inorganic and organic parts but may exhibit synergetic behaviors afforded by both moieties, making possible the development of novel physicochemical devices $[35,36]$. Moreover, they can be used as an intermediate step for the synthesis of covalent hydrides [37]. Grafted derivatives have higher thermal and chemical stability, which is required for practical applications in an aggressive environment or further chemical modification [38]. In addition, by their exfoliation, such compounds can be used to obtain perovskite monolayers with a surface modified by organic molecules. The latter moderates both the aggregation stability of these monolayers in various solutions and their physicochemical properties [39-41].

Layered perovskite-like titanates $\mathrm{H}_{2} \mathrm{Ln}_{2} \mathrm{Ti}_{3} \mathrm{O}_{10}(\mathrm{Ln}=\mathrm{La}$ or lanthanide) are the protonated forms of the Ruddlesden-Popper phases $\mathrm{A}_{2} \mathrm{Ln}_{2} \mathrm{Ti}_{3} \mathrm{O}_{10}$ with the thickness of the perovskite layer $n=3$. Since $\mathrm{TiO}_{6}$ octahedra in these compounds have unequal $\mathrm{B}-\mathrm{O}$ distances due to the different local surroundings of oxygen anions, interlayer alkali cations are sufficiently mobile. These titanates demonstrate ionic conductivity [42] and pronounced ion exchange properties [43,44].

Titanates $\mathrm{H}_{2} \mathrm{La}_{2} \mathrm{Ti}_{3} \mathrm{O}_{10}$ are known to be able to form some inorganic-organic derivatives, with $n$-alkylamines [45,46] and $n$-alcohols [28] possessing the chain lengths of three carbon atoms and higher. At the same time, there are no detailed data on hybrids with the simplest representatives of amines and alcohols. Besides this, the literature does not cover the issue of obtaining hybrids with amino alcohols-bifunctional organic substances potentially capable of the simultaneous formation of both noncovalent and covalent bonds with perovskite slabs. All types of hybrids may have their own application fields, and it is important to monitor the product yield while developing synthetic methods.

Nuclear magnetic resonance (NMR) is a convenient tool for such monitoring due to its sensitivity to the electron density distribution in the vicinity of the resonating nucleus and, hence, to the type of a chemical bond [47]. Moreover, this technique provides information on the dynamics of intercalated species [10,48-50] and is successfully applied to study organic-inorganic-layered materials [10,48,51-53].

In this study, we used multinuclear NMR to characterize organic-inorganic hybrids based on the layered perovskite-like titanate $\mathrm{H}_{2} \mathrm{La}_{2} \mathrm{Ti}_{3} \mathrm{O}_{10}$ and lower amines (methylamine), alcohols (methanol), and amino alcohols (monoethanolamine), as well as $n$-butylamine. The NMR investigations were supported by the structural, elemental, morphological, and thermal analyses of the studied organic-inorganic hybrids.

\section{Results and Discussion}

The organic-inorganic hybrids were prepared according to the method described in Section 3. Further, in the text, tables, and figures, the studied materials will be denoted as follows: the layered protonated perovskite, $\mathrm{H}_{2} \mathrm{La}_{2} \mathrm{Ti}_{3} \mathrm{O}_{10} \cdot x \mathrm{H}_{2} \mathrm{O}-\mathrm{HLT}_{3}$, the methylamine derivative, $\mathrm{H}_{2} \mathrm{La}_{2} \mathrm{Ti}_{3} \mathrm{O}_{10} \times$ $\mathrm{MeNH}_{2}-\mathrm{HLT}_{3} \times \mathrm{MeNH}_{2}$, the $n$-butylamine derivative, $\mathrm{H}_{2} \mathrm{La}_{2} \mathrm{Ti}_{3} \mathrm{O}_{10} \times \mathrm{BuNH}_{2}-\mathrm{HLT}_{3} \times \mathrm{BuNH}_{2}$, the methanol derivative, $\mathrm{H}_{2} \mathrm{La}_{2} \mathrm{Ti}_{3} \mathrm{O}_{10} \times \mathrm{MeOH}-\mathrm{HLT}_{3} \times \mathrm{MeOH}$, and the monoethanolamine hybrid, $\mathrm{H}_{2} \mathrm{La}_{2} \mathrm{Ti}_{3} \mathrm{O}_{10} \times$ MEA-HLT $3 \times$ MEA. 


\subsection{XRD Analysis}

To prove the formation of organic-inorganic hybrids, the materials synthesized were characterized by X-ray-diffraction (XRD) at each synthetic stage. Figure 1 demonstrates the XRD patterns of the initial protonated form and single-phase organic-inorganic compounds obtained under optimized conditions. More information can be found in the Supplementary Materials: Table S1 and Figures S1-S5. In all cases, the reflections observed are amenable to indexing in the tetragonal system. Formation of the hybrids is accompanied by a noticeable increase in the c lattice parameter, which is known to be directly related to their interlayer distance $d$, whereas the lattice parameter is seen to stay almost unchanged (Table 1). The observed increase in the interlayer distance is generally consistent with the molecule sizes of methylamine $(\sim 3 \AA)$, n-butylamine $(\sim 6.7 \AA)$, and a methyl group $(\sim 2 \AA)$ of methanol (assuming grafting) if we take into account the additional expansion caused by intercalated water molecules and possible bilayer arrangement. At the same time, the interlayer distance of the monoethanolamine hybrid is consistent with the single monoethanolamine molecule size (5.3 $\mathrm{A})$, similar to what was observed in the case of the $\mathrm{HLnTiO}_{4}(\mathrm{Ln}=\mathrm{La}$ and $\mathrm{Nd})$ hybrids studied earlier [54].

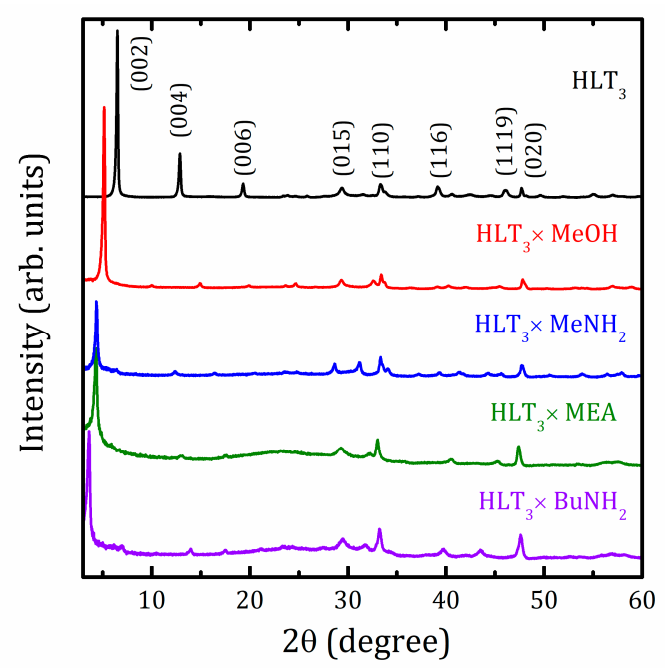

Figure 1. X-ray-diffraction (XRD) patterns of the initial $\mathrm{H}_{2} \mathrm{La}_{2} \mathrm{Ti}_{3} \mathrm{O}_{10} \cdot x \mathrm{H}_{2} \mathrm{O}\left(\mathrm{HLT}_{3}\right)$, and organic-inorganic $\mathrm{HLT}_{3} \times \mathrm{MeOH}, \mathrm{HLT}_{3} \times \mathrm{MeNH}_{2}, \mathrm{HLT}_{3} \times \mathrm{MEA}$, and $\mathrm{HLT}_{3} \times \mathrm{BuNH}_{2}$ compounds.

Table 1. Lattice parameters ( $a$ and $c$ indexed in the tetragonal system) and interlayer distances $d$ of the initial protonated titanate and its inorganic derivatives. $\mathrm{HLT}_{3}: \mathrm{H}_{2} \mathrm{La}_{2} \mathrm{Ti}_{3} \mathrm{O}_{10} \cdot x \mathrm{H}_{2} \mathrm{O}$.

\begin{tabular}{cccc}
\hline Sample & $\boldsymbol{a}(\mathbf{\AA})$ & $\boldsymbol{c}(\AA)$ & $\boldsymbol{d}(\mathbf{\AA})$ \\
\hline $\mathrm{HLT}_{3}$ & 3.809 & 27.55 & 13.78 \\
$\mathrm{HLT}_{3} \times \mathrm{MeNH}_{2}$ & 3.830 & 39.94 & 18.97 \\
$\mathrm{HLT}_{3} \times \mathrm{BuNH}_{2}$ & 3.828 & 24.23 & 24.23 \\
$\mathrm{HLT}_{3} \times \mathrm{MeOH}$ & 3.800 & 35.40 & 17.70 \\
$\mathrm{HLT}_{3} \times \mathrm{MEA}$ & 3.832 & 38.97 & 19.49 \\
\hline
\end{tabular}

\subsection{Raman and IR Spectroscopy}

Raman spectra of the initial protonated form and obtained hybrid compounds are shown in Figure 2. The fact of the formation of the hybrid is confirmed by the appearance of characteristic bands, which are not observed in the spectra of the precursor-stretching of $\mathrm{C}-\mathrm{H}\left(2800-3000 \mathrm{~cm}^{-1}\right)$ and $\mathrm{N}-\mathrm{H}\left(3225 \mathrm{~cm}^{-1}\right)$ bonds, as well as latitudinal vibrations of methyl $\left(1480 \mathrm{~cm}^{-1}\right)$, methylene $\left(1460 \mathrm{~cm}^{-1}\right)$, amino $\left(1560-1580 \mathrm{~cm}^{-1}\right)$, and C-O-H $\left(1340 \mathrm{~cm}^{-1}\right)$ fragments. In the low-frequency region $\left(<350 \mathrm{~cm}^{-1}\right)$, which contains complex vibrations of the interlayer components linked to the oxygen of $\mathrm{TiO}_{6}$ octahedra, the main changes are related to the symmetric stretching mode $\left(v_{\mathrm{s}}\right)$ of the axial $\mathrm{Ti}-\mathrm{O}$ bonds $\left(810 \mathrm{~cm}^{-1}\right.$ for the protonated form), which splits into two bands $\left(765\right.$ and $\left.895 \mathrm{~cm}^{-1}\right)$ 
during amine intercalation, which points at the existence of two types of octahedra with unequal axial Ti-O distances. Bands of asymmetric stretching mode $\left(v_{\mathrm{as}}\right)$ of the closest to the interlayer space $\mathrm{TiO}_{6}$ octahedra (500-600 cm-1) and vibrations of the central weakly distorted octahedra (470 and $685 \mathrm{~cm}^{-1}$ ) do not experience noticeable changes during hybrids formation, indicating the preservation of the perovskite structure $[55,56]$.

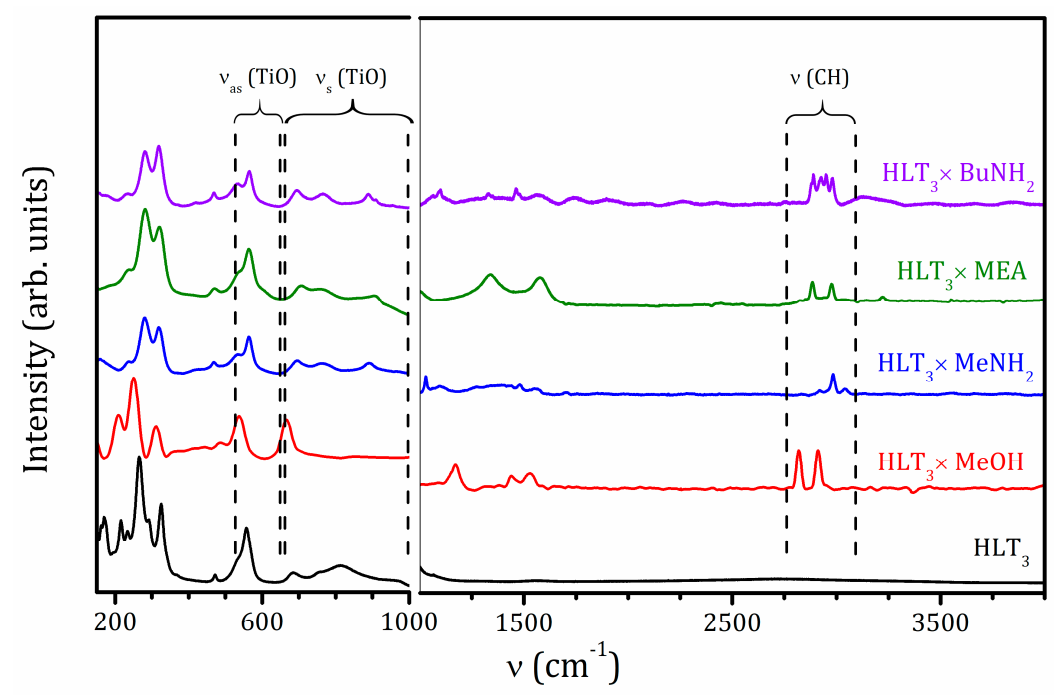

Figure 2. Raman spectra of the initial $\mathrm{HLT}_{3}$ and organic-inorganic $\mathrm{HLT}_{3} \times \mathrm{MeOH}, \mathrm{HLT}_{3} \times \mathrm{MeNH}_{2}$, $\mathrm{HLT}_{3} \times \mathrm{MEA}$, and $\mathrm{HLT}_{3} \times \mathrm{BuNH}_{2}$ compounds.

For the methanolic hybrid $\mathrm{HLT}_{3} \times \mathrm{MeOH}$, the band at $810 \mathrm{~cm}^{-1}$, which is typical of the protonated form, does not exist; instead, a new band at $665 \mathrm{~cm}^{-1}$ appears. This may be related to the formation of covalent Ti-O-C bonds. Additionally, new bands at about $485 \mathrm{~cm}^{-1}$ emerge, and the bands at $560-570 \mathrm{~cm}^{-1}$, which can be referred to as the asymmetric stretching mode of $\mathrm{TiO}_{6}$ octahedra, shift to $540-550 \mathrm{~cm}^{-1}$, suggesting the noticeable influence of the methoxy groups on the perovskite octahedra. Moreover, bands associated with the $\mathrm{C}-\mathrm{O}-\mathrm{H}$ fragment vibrations that present in the spectra of the pure methanol, are not observed. These facts indicate that the interlayer space of the methanolic hybrid does actually contain not the molecular methanol but its methoxy groups covalently bound to the inorganic frame. It was previously shown that, depending on the synthesis conditions, amino alcohols can be incorporated with or without the formation of a covalent bond [37]. In the case of the monoethanolamine derivative, $\mathrm{HLT}_{3} \times \mathrm{MEA}$, the observed vibrations of the $\mathrm{C}-\mathrm{O}-\mathrm{H}$ fragment $\left(1340 \mathrm{~cm}^{-1}\right)$ indicate the partial or complete presence of the interlayer monoethanolamine in a nongrafted form.

The Infrared (IR) absorption spectra of the obtained hybrids can be found in Supplementary Materials Figure S6. They are in fair agreement with the Raman data and, also, demonstrate the latitudinal vibrations of water $\left(1630 \mathrm{~cm}^{-1}\right)$ and stretching of its $\mathrm{O}-\mathrm{H}$ fragments (wide band at 2800-3500 $\mathrm{cm}^{-1}$ ), suggesting the presence of intercalated water in the samples.

\subsection{Thermal Analysis}

The degree of hydration and the temperatures corresponding to the loss of water and organic molecules were determined by thermogravimetric analysis with simultaneous mass spectrometric identification of the released gases (STA-MS). The thermal gravimetric (TG) curves are shown in Figure 3. The more detailed information on the STA-MS analysis can be found in Supplementary Materials Figures S7-S10. The thermal degradation of the methylamine hybrid $\mathrm{HLT}_{3} \times \mathrm{MeNH}_{2}$ in the oxidizing atmosphere proceeds as deintercalation. The evacuation of the intercalated water takes place at temperatures above $50{ }^{\circ} \mathrm{C}$, followed by methylamine evacuation above $100{ }^{\circ} \mathrm{C}$, giving the deintercalated protonated form, which decomposes at $300-500{ }^{\circ} \mathrm{C}$. $\mathrm{HLT}_{3} \times \mathrm{BuNH}_{2}$ undergoes thermal 
degradation mainly in the same way as $\mathrm{HLT}_{3} \times \mathrm{MeNH}_{2}$. The only difference is observed at temperatures above $500{ }^{\circ} \mathrm{C}$; in $\mathrm{HLT}_{3} \times \mathrm{BuNH}_{2}$, there is a noticeable mass gain stage, obviously associated with oxidation, which is replaced by the further mass loss stage related to the carbon dioxide release; see Supplementary Materials Figures S7 and S8. This suggests the existence of some remaining carbon-containing substances in the sample after the first stage of the decomposition. The same mass gain stages are also observed for the $\mathrm{HLT}_{3} \times \mathrm{MeOH}$ and $\mathrm{HLT}_{3} \times \mathrm{MEA}$ compounds.

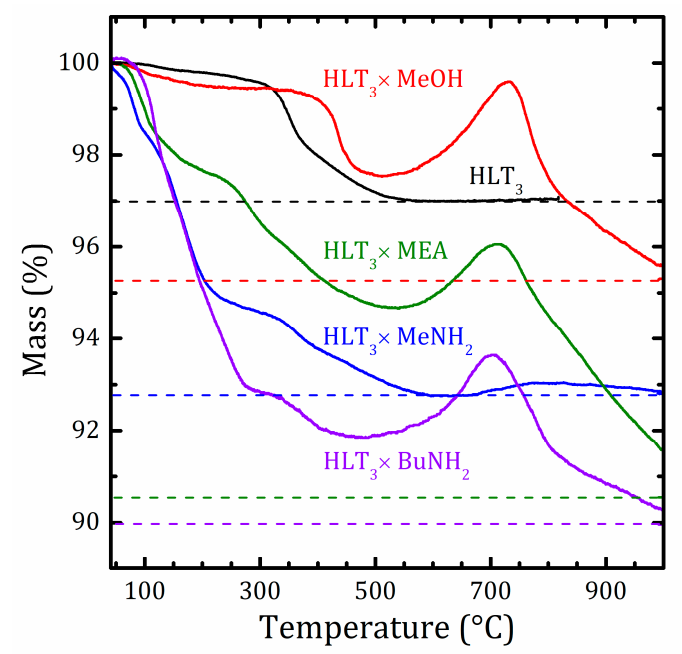

Figure 3. Thermal gravimetric (TG) curves for the initial $\mathrm{HLT}_{3}$ and organic-inorganic $\mathrm{HLT}_{3} \times \mathrm{MeOH}$, $\mathrm{HLT}_{3} \times \mathrm{MeNH}_{2}, \mathrm{HLT}_{3} \times \mathrm{MEA}$, and $\mathrm{HLT}_{3} \times \mathrm{BuNH}_{2}$ compounds. Masses after the final isothermal step are shown by dashed lines.

According to the STA-MS data (see Supplementary Materials Figure S9), the organic part of $\mathrm{HLT}_{3}$ $\times \mathrm{MeOH}$ does not decompose up to relatively high temperatures (approximately $300{ }^{\circ} \mathrm{C}$ ), and the deintercalation of molecular methanol does not take place. This confirms the covalent nature of methanol binding. The $\mathrm{HLT}_{3} \times$ MEA hybrid, on the one hand, is a much more thermally stable substance as compared to $\mathrm{HLT}_{3} \times \mathrm{MeNH}_{2}$ and $\mathrm{HLT}_{3} \times \mathrm{BuNH}_{2}$. On the other hand, the decomposition of its organic part starts at approximately $250{ }^{\circ} \mathrm{C}$, which is lower than the temperature of the $\mathrm{HLT}_{3} \times$ $\mathrm{MeOH}$ decomposition. This inexplicitly indicates a possible noncovalent nature of the obtained $\mathrm{HLT}_{3}$ $\times$ MEA compound.

The resulting compositions assigned to the obtained hybrids, as well as the temperature of their decomposition, as determined from the thermal analysis, are listed in Table 2.

Table 2. The composition and decomposition temperature $\left(T_{\mathrm{d}}\right)$ for the studied compounds. TG: thermal gravimetric.

\begin{tabular}{|c|c|c|c|}
\hline Sample & Composition & $\begin{array}{c}\text { Total Mass Loss in } \\
\text { TG }(\%)\end{array}$ & $T_{\mathrm{d}}\left({ }^{\circ} \mathrm{C}\right)$ \\
\hline $\mathrm{HLT}_{3}$ & $\mathrm{H}_{2} \mathrm{La}_{2} \mathrm{Ti}_{3} \mathrm{O}_{10}\left(\mathrm{H}_{2} \mathrm{O}\right)_{0.05}$ & 3.01 & 280 \\
\hline $\mathrm{HLT}_{3} \times \mathrm{MeNH}_{2}$ & $\mathrm{H}_{2} \mathrm{La}_{2} \mathrm{Ti}_{3} \mathrm{O}_{10}\left(\mathrm{MeNH}_{2}\right)_{0.75}\left(\mathrm{H}_{2} \mathrm{O}\right)_{0.20}$ & 7.29 & 75 \\
\hline $\mathrm{HLT}_{3} \times \mathrm{BuNH}_{2}$ & $\mathrm{H}_{2} \mathrm{La}_{2} \mathrm{Ti}_{3} \mathrm{O}_{10}\left(\mathrm{BuNH}_{2}\right)_{0.60}\left(\mathrm{H}_{2} \mathrm{O}\right)_{0.20}$ & 10.3 & 75 \\
\hline $\mathrm{HLT}_{3} \times \mathrm{MeOH}$ & $\mathrm{H}_{1.3} \mathrm{La}_{2} \mathrm{Ti}_{3} \mathrm{O}_{9.3}(\mathrm{MeO})_{0.75}\left(\mathrm{H}_{2} \mathrm{O}\right)_{0.05}$ & 4.75 & 300 \\
\hline $\mathrm{HLT}_{3} \times \mathrm{MEA}$ & $\mathrm{H}_{2} \mathrm{La}_{2} \mathrm{Ti}_{3} \mathrm{O}_{10}(\mathrm{MEA})_{0.65}\left(\mathrm{H}_{2} \mathrm{O}\right)_{0.10}$ & 9.47 & 250 \\
\hline
\end{tabular}

\subsection{Scanning Electron Microscopy}

According to the scanning electron microscopy (SEM) data (Figure 4), during the intercalation and grafting reactions, both sizes and the lamellar forms of the particles are predominantly retained. Although the SEM images of the $\mathrm{HLT}_{3} \times \mathrm{MeNH}_{2}$ and $\mathrm{HLT}_{3} \times \mathrm{BuNH}_{2}$ organic-inorganic derivatives clearly confirm their incipient lamination, no other significant morphological changes are observed. 
Thus, all the reactions of the hybrid formation follow the topochemical mechanism: the structure of the inorganic part of the hybrids stays almost native and, consequently, saves all the useful properties of the initial perovskite-like compound, which may be combined with those of an organic part, giving new materials.
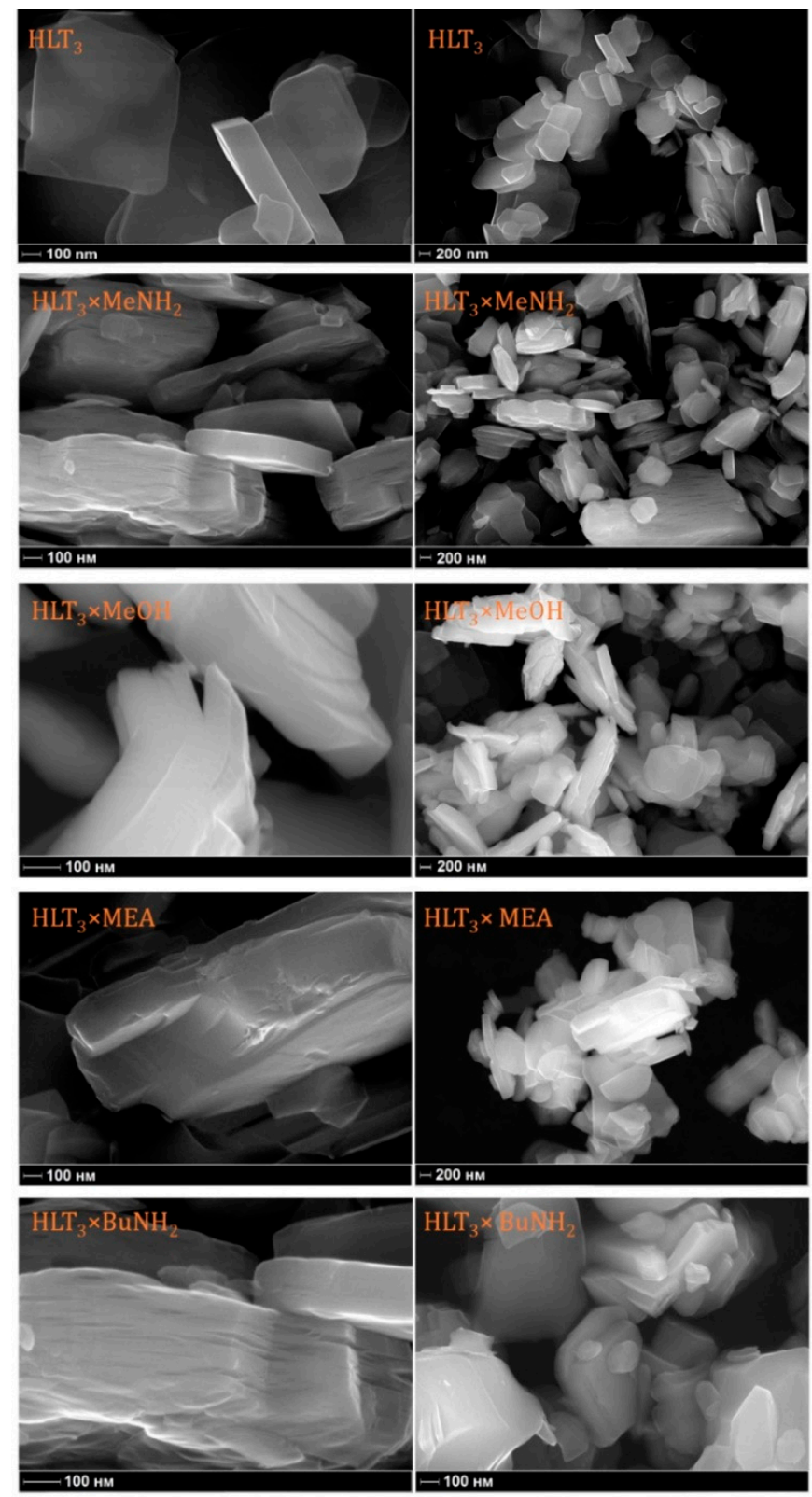

Figure 4. SEM images of the initial $\mathrm{HLT}_{3}$ and organic-inorganic $\mathrm{HLT}_{3} \times \mathrm{MeOH}, \mathrm{HLT}_{3} \times \mathrm{MeNH}_{2}$, $\mathrm{HLT}_{3} \times \mathrm{MEA}$, and $\mathrm{HLT}_{3} \times \mathrm{BuNH}_{2}$ compounds.

\subsection{NMR Studies}

To establish whether the hybrids are intercalation compounds or grafted derivatives, ${ }^{1} \mathrm{H}-,{ }^{13} \mathrm{C}-$, and ${ }^{15} \mathrm{~N}-\mathrm{NMR}$ studies were performed. ${ }^{1} \mathrm{H}-\mathrm{NMR}$ has been used to characterize the distribution of mobile protons between different fractions in confined geometry. Different hydrogen bond environments exhibit different chemical shifts when the proton exchange between the fractions is slow within a time scale of ms [57]. ${ }^{1} \mathrm{H}-\mathrm{NMR}$ chemical shift of a mobile proton can be as large as $21.7 \mathrm{ppm}$ [58]. ${ }^{1} \mathrm{H}-\mathrm{NMR}$ chemical shift of bulk water is $4.8 \mathrm{ppm}$. The chemical shift of an average $\mathrm{H}^{+} / \mathrm{H}_{2} \mathrm{O}$ signal depends on the concentration of $\mathrm{H}^{+}$and, in a binary mixture, is larger than $5 \mathrm{ppm}$. Isolated surface hydroxyl groups 
resonate below 2 ppm [59]. The chemical shift of an average $\mathrm{HO} / \mathrm{H}_{2} \mathrm{O}$ signal depends on the amount of water and, in a binary mixture, is smaller than $5 \mathrm{ppm} .{ }^{13} \mathrm{C}-\mathrm{NMR}$ has been used to characterize the rotational mobility of organic moieties. Chemical shift is a tensor quantity. The anisotropy of this tensor decreases if a moiety reorients fast within a time scale of ms [60]. ${ }^{15} \mathrm{~N}-\mathrm{NMR}$ has been used to characterize the protonation state of amino moieties [61].

\subsubsection{NMR Studies of the $\mathrm{HLT}_{3} \times \mathrm{MeOH}$ Derivative}

Figure 5a,b represents ${ }^{13} \mathrm{C}\left\{{ }^{1} \mathrm{H}\right\}$ cross-polarization $(\mathrm{CP})$ NMR spectra of the methanol derivative recorded under magic angle spinning (MAS) and static conditions, respectively. The ${ }^{13} \mathrm{C}\left\{{ }^{1} \mathrm{H}\right\} \mathrm{CP} / \mathrm{MAS}$ spectrum shows a line at $66.2 \mathrm{ppm}$. The ${ }^{13} \mathrm{C}$ chemical shift tensor of this $\mathrm{O}-\mathrm{CH}_{3}$ moiety is axially symmetric; its span is about $100 \mathrm{ppm}$. Therefore, this moiety cannot change its spatial orientation within the time scale of ms. The value of its isotropic chemical shift is low-field-shifted as compared to that of methanol (49 ppm). In contrast, the isotropic chemical shift, the symmetry, and the span of the tensor under discussion are similar to that of the $\mathrm{O}-\mathrm{CH}_{3}$ moiety of $\mathrm{Ti}\left(\mathrm{CH}_{3} \mathrm{O}\right)_{4}($ Figure $5 \mathrm{c}, \mathrm{d})$. Therefore, the $\mathrm{O}-\mathrm{CH}_{3}$ moieties of the methanol derivative are covalently bonded to the inorganic matrix, $\mathrm{Ti}-\mathrm{O}-\mathrm{CH}_{3}$.

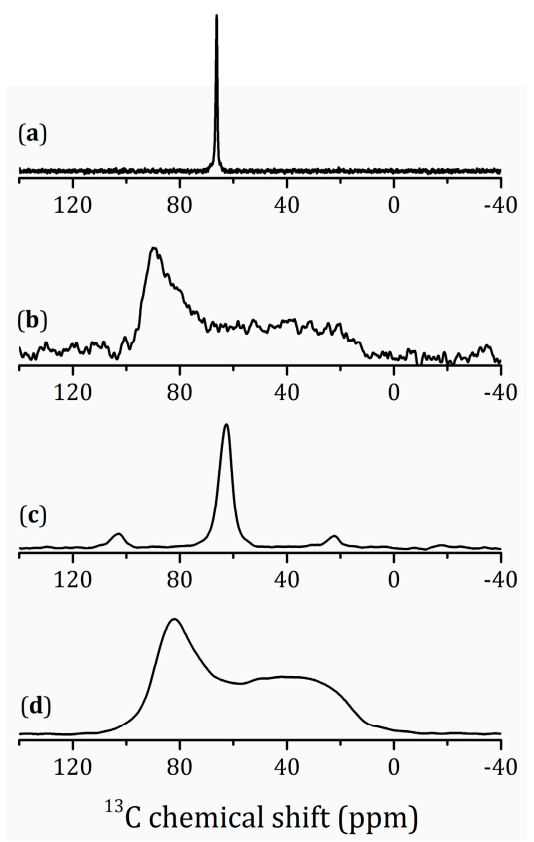

Figure 5. ${ }^{13} \mathrm{C}\left\{{ }^{1} \mathrm{H}\right\}$ cross-polarization $(\mathrm{CP}) \mathrm{NMR}$ spectra of $\mathrm{HTL}_{3} \times \mathrm{MeOH}$ under magic angle spinning (MAS) at $v_{\text {rot }}=14 \mathrm{kHz}(\mathbf{a})$ and static (b) conditions in magnetic field $9.4 \mathrm{~T}$ and ${ }^{13} \mathrm{C}-\mathrm{NMR}$ spectra of $\mathrm{Ti}\left(\mathrm{CH}_{3} \mathrm{O}\right)_{4}$ under MAS at $v_{\text {rot }}=5 \mathrm{kHz}(\mathbf{c})$ and static $(\mathbf{d})$ conditions in magnetic field $7 \mathrm{~T}$.

Figure 6a shows the ${ }^{1} \mathrm{H}$ MAS NMR spectrum of the methanol derivative. The spectral lines are very broad, even at $14 \mathrm{kHz}$ of spinning frequency. Consequently, both the rotational diffusion of the $\mathrm{CH}_{3}$ moieties and proton exchange are slow in this sample. The spectrum can be deconvoluted into three main peaks. The line at $3.4 \mathrm{ppm}$ can be attributed to the $\mathrm{CH}_{3}$ moieties. The lines at 11 and 7 ppm can be attributed to the interlayer $\mathrm{H}^{+}$in regular sites in water-poor and water-rich environments, respectively [50,62]. These results can be compared to the ${ }^{1} \mathrm{H}$ MAS NMR spectrum of $\mathrm{H}_{2} \mathrm{La}_{2} \mathrm{Ti}_{3} \mathrm{O}_{10}\left(\mathrm{H}_{2} \mathrm{O}\right)_{0.07}$ (Figure $6 \mathrm{~b}$ ). In this sample, the lines corresponding to the water-poor (11.7 ppm) and water-rich $(8.5 \mathrm{ppm})$ environments are narrow, which means that proton mobility in this environment is high. The line at $13.8 \mathrm{ppm}$ can be attributed to the interlayer $\mathrm{H}^{+}$in a water-free site. The mobility of these species is restricted, and the line is broad. Note that the modification of the inorganic matrix strongly affects the mobility and the distribution of the interlayer $\mathrm{H}^{+}$. The high-field signals in these spectra can belong to residual $\mathrm{TiOH}$ groups and surface-bound water [63-65]. 


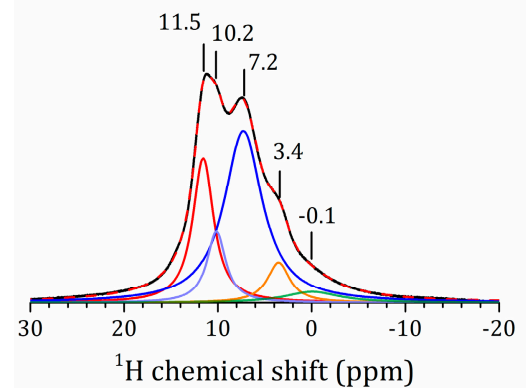

(a)

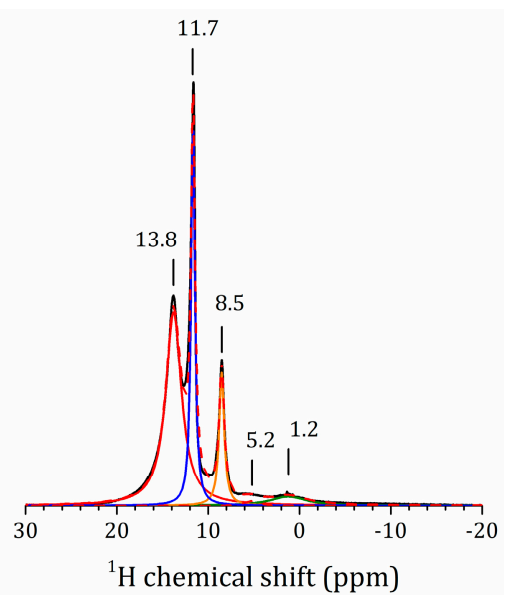

(b)

Figure 6. ${ }^{1} \mathrm{H}$ MAS NMR spectra of $\mathrm{HLT}_{3} \times \mathrm{MeOH}(\mathbf{a})$ and $\mathrm{HLT}_{3}(\mathbf{b})$ and their decomposition. Dashed lines show the total fit.

\subsubsection{NMR Studies of the $\mathrm{HLT}_{3} \times \mathrm{MeNH}_{2}$ and $\mathrm{HLT}_{3} \times \mathrm{BuNH}_{2}$ Derivatives}

${ }^{13} \mathrm{C}$-NMR spectra of the methylamine and $n$-butylamine derivatives are shown in Figure 7. For $\mathrm{HLT}_{3} \times \mathrm{MeNH}_{2}$ in the ${ }^{13} \mathrm{C}\left\{{ }^{1} \mathrm{H}\right\} \mathrm{CP} / \mathrm{MAS}$ spectrum, only one line at $25.3 \mathrm{ppm}$ is observed (see Figure 7a), which is in fair agreement with the position of the methyl carbon for the methylammonium cation.
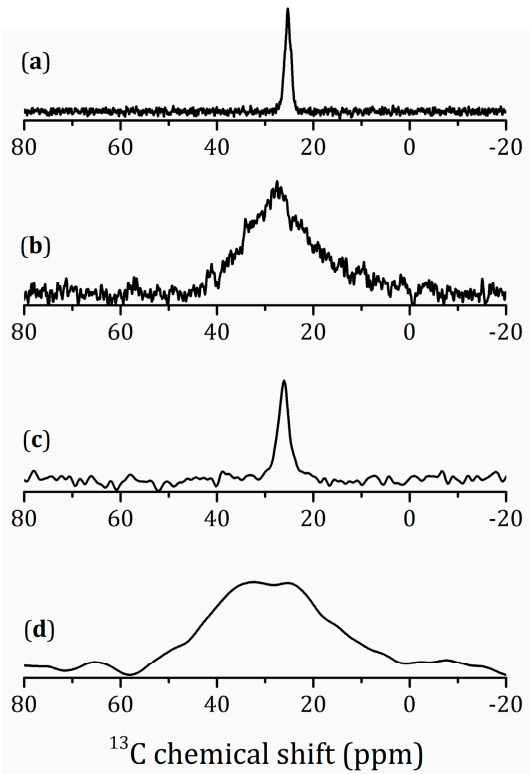
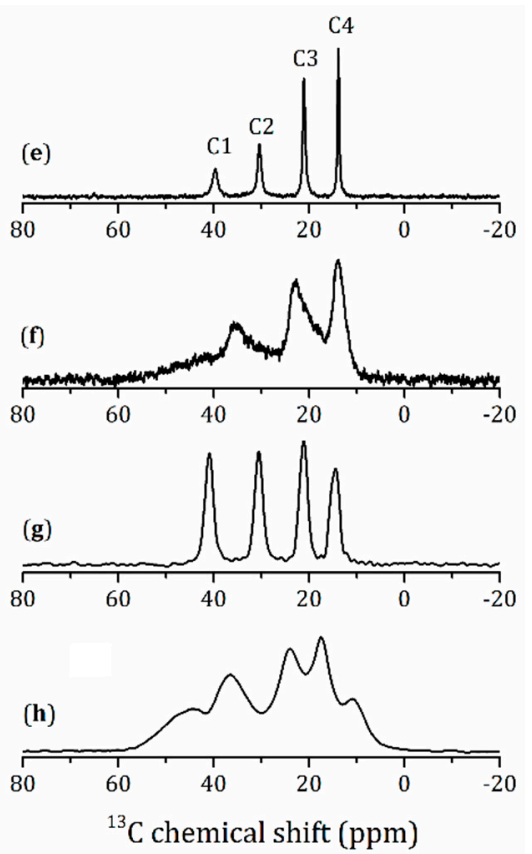

Figure 7. ${ }^{13} \mathrm{C}\left\{{ }^{1} \mathrm{H}\right\} \mathrm{CP}$ NMR spectra of $\mathrm{HLT}_{3} \times \mathrm{MeNH}_{2}$ under MAS at $v_{\text {rot }}=14 \mathrm{kHz}(\mathbf{a})$ and static (b) conditions in magnetic field $9.4 \mathrm{~T} .{ }^{13} \mathrm{C}-\mathrm{NMR}$ spectra of $\mathrm{MeNH}_{2} \mathrm{HCl}$ under MAS at $v_{\text {rot }}=5 \mathrm{kHz}$ (c) and static (d) conditions in magnetic field 7 T. $\left.{ }^{13} \mathrm{C}_{\{}{ }^{1} \mathrm{H}\right\} \mathrm{CP}$ NMR spectra of $\mathrm{HLT}_{3} \times \mathrm{BuNH}_{2}$ under MAS at $v_{\text {rot }}=14 \mathrm{kHz}$ (e) and static (f) conditions in magnetic field 9.4 T. ${ }^{13} \mathrm{C}-\mathrm{NMR}$ spectra of $\mathrm{BuNH}_{2} \mathrm{HCl}$ under MAS at $\gamma_{\text {rot }}=5 \mathrm{kHz}$ (g) and static (h) conditions in magnetic field $7 \mathrm{~T}$.

The static spectrum, Figure $7 \mathrm{~b}$, represents the characteristic powder pattern on an anisotropic magnetic shielding tensor with a nonaxial symmetry. Therefore, the reorientational diffusion of these methylamine molecules is slow on the NMR time scale of ms. This gives evidence for the intercalation 
of methylamine. Note that this peak represents averaging over a variety of slightly different tensors, because the local environment of each individual methylammonium cation is different. Therefore, the principal values of these magnetic shielding tensors cannot be evaluated from this spectrum. This situation is typical for amorphous solids [66], surface functional groups [67], and molecules in confined geometry [68].

The spectra for powder $\mathrm{CH}_{3} \mathrm{NH}_{2} \mathrm{HCl}$ are given for a comparison in Figure $7 \mathrm{c}$, d. The line position is almost unchanged. However, the powder pattern shows different anisotropy that can be related to the amorphous nature of this $\mathrm{CH}_{3} \mathrm{NH}_{2} \mathrm{HCl}$ sample. We are not aware about any data on the existence of crystalline $\mathrm{CH}_{3} \mathrm{NH}_{2} \mathrm{HCl}$.

The ${ }^{13} \mathrm{C}\left\{{ }^{1} \mathrm{H}\right\} \mathrm{CP} / \mathrm{MAS}$ NMR spectrum of the $n$-butylamine derivative exhibits four lines at 39.7, 30.4, 21.1, and $13.8 \mathrm{ppm}$ (Figure 7e). This figure shows the attribution of the lines to the four chemically different carbons of $n$-butylamine. The numeration starts from the amino group. It is obvious that the line width of these peaks decreases with the distance from the amino group. This trend remains valid for the anisotropy of the corresponding tensors (Figure 7f). In contrast, both the line width of the isotropic peaks and the anisotropy of the tensors are similar for all four carbons in a polycrystalline $\mathrm{BuNH}_{2} \mathrm{HCl}$ (Figure $7 \mathrm{~g}$,h). Therefore, the reorientational mobility of the $n$-butyl moieties in $\mathrm{HLT}_{3} \times$ $\mathrm{BuNH}_{2}$ is not sterically hindered.

The ${ }^{15} \mathrm{~N}\left\{{ }^{1} \mathrm{H}\right\} \mathrm{CP} / \mathrm{MAS}$ NMR spectra of $\mathrm{HLT}_{3} \times \mathrm{MeNH}_{2}$ and $\mathrm{HLT}_{3} \times \mathrm{BuNH}_{2}$ show single lines at $32.52 \mathrm{ppm}$ and $44.01 \mathrm{ppm}$, respectively. The ${ }^{15} \mathrm{~N}$ chemical shift $\delta\left({ }^{15} \mathrm{~N}\right)$ of neat $\mathrm{MeNH}_{2}$ and $\left(\mathrm{MeNH}_{3}\right)^{+}$in water is $\sim 3$ and $35 \mathrm{ppm}$, respectively $[69,70]$. The $\delta\left({ }^{15} \mathrm{~N}\right)$ of neat $\mathrm{BuNH}_{2}$ and $\left(\mathrm{BuNH}_{3}\right)^{+} \mathrm{Cl}^{-}$in methanol is $\sim 22$ and $34 \mathrm{ppm}$, respectively [71,72].

Altogether, it points out that, in the both methylamine and $n$-butylamine derivatives, the organic species are intercalated in the form of methyl- or butylammonium cations. Their $\left(-\mathrm{NH}_{3}\right)^{+}$moieties are immobilized due to electrostatic interactions with negatively charged perovskite layers, while the aliphatic residues remain flexible.

The ${ }^{1} \mathrm{H}$ MAS NMR spectra of these amine derivatives are shown in Figure 8. The lines of the aliphatic residues are broad and overlap. Consequently, the libration of these residues is sterically hindered. The chemical shifts of the interlayer $\mathrm{H}^{+}$and the $-\left(\mathrm{NH}_{3}\right)^{+}$moieties are in the range 11-8 ppm. The presence of several spectral lines indicates that the distribution of the organic species in the samples is not homogeneous.

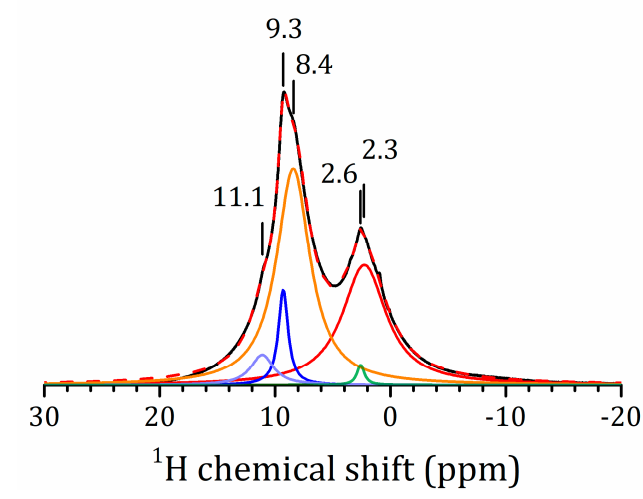

(a)

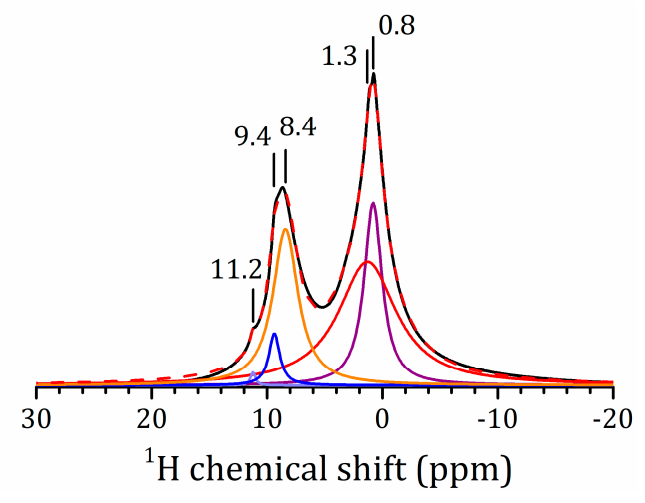

(b)

Figure 8. ${ }^{1} \mathrm{H}$ MAS NMR spectra of $\mathrm{HLT}_{3} \times \mathrm{MeNH}_{2}$ (a) and $\mathrm{HLT}_{3}$ (b) and their decomposition. Dashed lines show the total fit.

\subsubsection{NMR Studies the $\mathrm{HLT}_{3} \times$ MEA Derivative}

The decomposition temperature of the monoethanolamine derivative is similar to that of the methanol derivative and is much higher as compared to that of the methylamine and $n$-butylamine derivatives (Table 2). This suggests that the methylene carbons of the monoethanolamine residues 
are covalently bound to the lattice oxygens. Figure 9a shows the ${ }^{13} \mathrm{C}\left\{{ }^{1} \mathrm{H}\right\} \mathrm{CP} / \mathrm{MAS}$ NMR spectrum of $\mathrm{HLT}_{3} \times$ MEA.

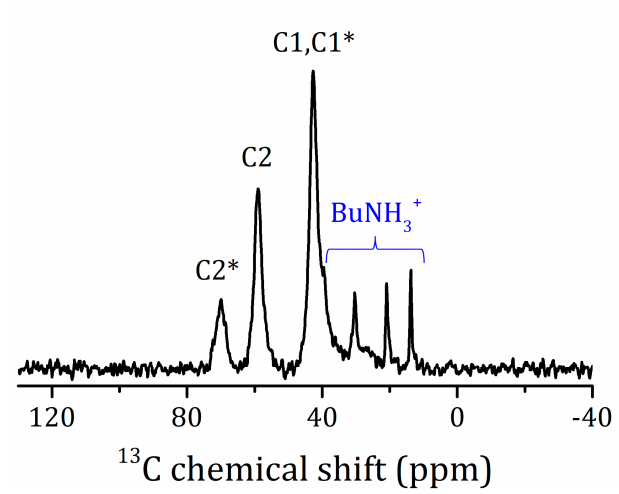

(a)

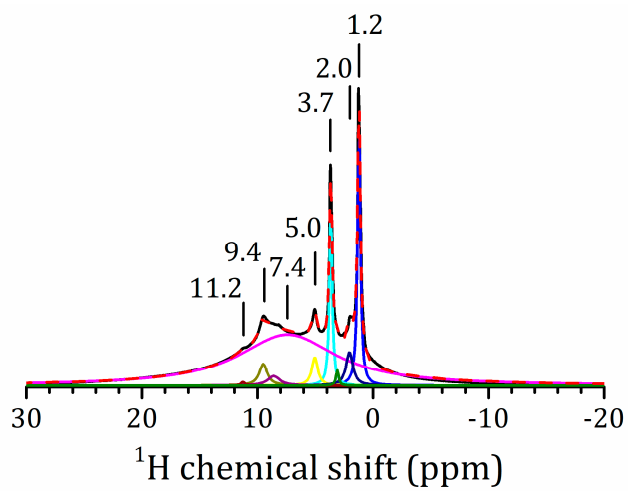

(b)

Figure 9. ${ }^{13} \mathrm{C}\left\{{ }^{1} \mathrm{H}\right\} \mathrm{CP} / \mathrm{MAS}(\mathbf{a})$ and ${ }^{1} \mathrm{H}$ MAS NMR (b) spectra of $\mathrm{HLT}_{3} \times$ MEA.

Besides the peaks of the residual $\mathrm{BuNH}_{3}{ }^{+}$, there are three new peaks at 42.6, 58.9, and $69.9 \mathrm{ppm}$. The first of these peaks obviously belongs to the $-\mathrm{CH}_{2}-\mathrm{NH}_{3}{ }^{+}$carbon atom ( $\mathrm{C} 1$ carbon) [73] The corresponding peak of $\mathrm{BuNH}_{3}{ }^{+}$has a similar chemical shift. The two other lines should be attributed to the $-\mathrm{O}-\mathrm{CH}_{2}$ - carbon atom. Therefore, in this sample, two different substituents at the oxygen atom are possible. The ${ }^{13} \mathrm{C}$ chemical shifts of isopropanol $\left(\left(\mathrm{CH}_{3}\right)_{2} \mathrm{CHOH}\right)$ and titanium isopropoxide $\left(\mathrm{Ti}\left(\mathrm{OCH}\left(\mathrm{CH}_{3}\right)_{2}\right)_{4}\right)$ are 25.3/63.7 and 26.6/76.2 ppm, respectively [74]. Consequently, the conversion of a HOC- moiety into a -TiOC- one has a small effect on the chemical shift of remote carbon nuclei. The signal of the-OC-moiety will be shifted to lower field by about $10 \mathrm{ppm}$. We conclude that the peak at $58.9 \mathrm{ppm}$ in the spectrum of the monoethanolamine derivative belongs to the $\mathrm{C} 2$ carbon of intercalated protonated MEA, $\mathrm{HOCH}_{2} \mathrm{CH}_{2} \mathrm{NH}_{3}{ }^{+}$[73]. In contrast, the peak at $69.9 \mathrm{ppm}$ belongs to $\mathrm{TiOCH}_{2} \mathrm{CH}_{2} \mathrm{NH}_{3}{ }^{+}$residues covalently bound to the inorganic matrix; we denote it as $\mathrm{C}^{*}$. Obviously, the peak of $\mathrm{Cl}^{*}$ of the grafted $\mathrm{TiOCH}_{2} \mathrm{CH}_{2} \mathrm{NH}_{3}{ }^{+}$coincides with that of $\mathrm{C} 1$ of the intercalate.

The ${ }^{1} \mathrm{H}$ spectrum of $\mathrm{HLT}_{3} \times$ MEA is not very informative (Figure $9 \mathrm{~b}$ ). The broad line centered at $7.4 \mathrm{ppm}$ includes all types of mobile protons in different environments and is very broadened, and it is impossible to select contributions from the interlayer $\mathrm{H}^{+}$, the $-\left(\mathrm{NH}_{3}\right)^{+}$, and $-\mathrm{NH}_{2}$ moieties. The narrow lines at 3.7 and $1.2 \mathrm{ppm}$ are more likely from mobile moieties of intercalated molecules.

\subsubsection{VCT Experiment to Study the Dynamics of Organic Molecules}

To study the dynamics of the organic molecules within the interlayer space, a ${ }^{13} \mathrm{C}\left\{{ }^{1} \mathrm{H}\right\} \mathrm{CP} / \mathrm{MAS}$ experiment with variable contact time (VCT) was carried out. Figure 10 represents the intensity of the carbon peaks of the organic molecules introduced in $\mathrm{HLT}_{3}$ as a function of contact time ${ }^{1} \mathrm{H}^{-13} \mathrm{C}$. The dependence of the signal intensity on the contact period during VCT can be described by the following Equation (1) [75]:

$$
I=I_{0}\left(1-\frac{T_{\mathrm{CH}}}{T_{1 \rho}(\mathrm{H})}\right)^{-1} \cdot\left[\exp \left(-\frac{\tau_{\mathrm{cp}}}{T_{1 \rho}(\mathrm{H})}\right)-\exp \left(-\frac{\tau_{\mathrm{cp}}}{T_{\mathrm{CH}}}\right)\right]
$$

where $T_{\mathrm{CH}}$ is the cross-polarization time of a chemical group generating the corresponding NMR signal. It determines the growing part of the signal intensity and reflects the efficiency of the cross-polarization transfer from the ${ }^{1} \mathrm{H}$ to ${ }^{13} \mathrm{C}$ nuclei. This parameter is normally different for carbons belonging to different functional groups. Its value, on the one hand, is determined by the number of protons near the carbon nucleus and, on the other hand, by the rigidity of the carbon bonding with the "lattice". The signal decay is governed by $T_{1 \rho}(\mathrm{H})$, which is the proton longitudinal relaxation time (in the rotating frame) associated to the corresponding functional group. 


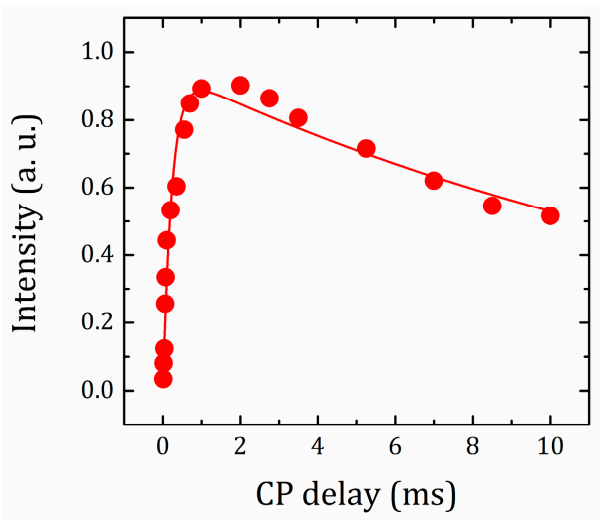

(a)

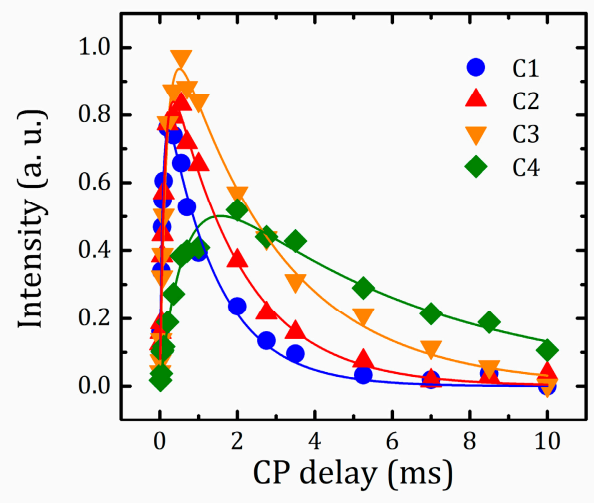

(c)

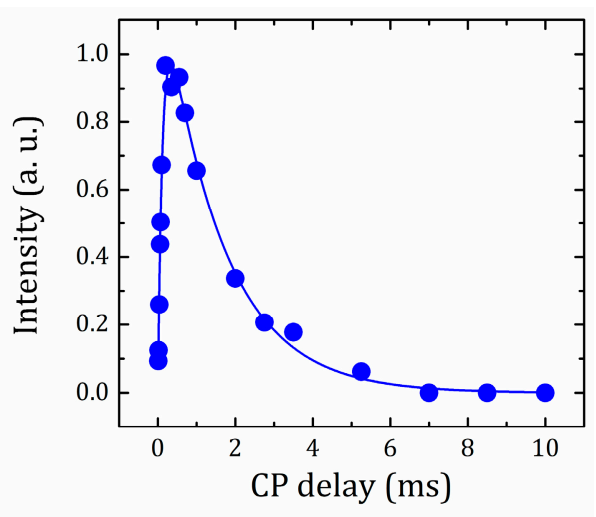

(b)

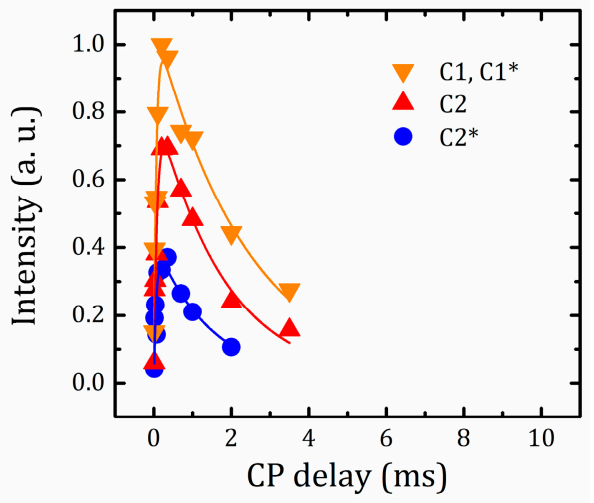

(d)

Figure 10. Integral peak intensity for carbon atoms in $\mathrm{HLT}_{3} \times \mathrm{MeOH}(\mathbf{a}), \mathrm{HLT}_{3} \times \mathrm{MeNH}_{2}(\mathbf{b}), \mathrm{HLT}_{3} \times$ $\mathrm{BuNH}_{2}(\mathbf{c})$, and $\mathrm{HLT}_{3} \times \mathrm{MEA}(\mathbf{d})$.

The $T_{\mathrm{CH}}$ and $T_{1 \rho}(\mathrm{H})$ parameters for all the carbon sites of the studied organic molecules, as determined from the dependencies shown in Figure 10 applying Equation (1), are listed in Table 3.

Table 3. Values of $T_{\mathrm{CH}}$ and $T_{1 \rho}(\mathrm{H})$ for the specific ${ }^{13} \mathrm{C}$ nuclei with an isotropic chemical shift $\delta_{\text {iso }}$ in the studied hybrids, as derived from ${ }^{1} \mathrm{H}_{-}{ }^{13} \mathrm{C}$ cross-polarization/magic angle spinning (CP/MAS) NMR measurements.

\begin{tabular}{ccccc}
\hline Compound & Carbon Site & $\boldsymbol{\delta}_{\text {iso }}(\mathbf{p p m})$ & $\boldsymbol{T}_{\mathbf{C H}}(\boldsymbol{\mu s})$ & $\boldsymbol{T}_{\mathbf{1} \boldsymbol{\rho}}(\mathbf{H})(\mathbf{m s})$ \\
\hline $\mathrm{HLT}_{3} \times \mathrm{MeOH}$ & $\mathrm{C}$ & $66.2 \pm 0.1$ & $233 \pm 29$ & $17.1 \pm 2.8$ \\
\hline $\mathrm{HLT}_{3} \times \mathrm{MeNH}_{2}$ & $\mathrm{C}$ & $25.2 \pm 0.1$ & $131 \pm 10$ & $1.5 \pm 0.1$ \\
\hline & $\mathrm{C} 1$ & $39.7 \pm 0.1$ & $79 \pm 6$ & $1.3 \pm 0.1$ \\
$\mathrm{HLT}_{3} \times \mathrm{BuNH}_{2}$ & $\mathrm{C} 2$ & $30.4 \pm 0.1$ & $129 \pm 9$ & $1.8 \pm 0.1$ \\
& $\mathrm{C} 3$ & $21.1 \pm 0.1$ & $182 \pm 13$ & $2.3 \pm 0.2$ \\
& $\mathrm{C} 4$ & $13.8 \pm 0.1$ & $700 \pm 93$ & $5.8 \pm 0.6$ \\
\hline \multirow{2}{*}{$\mathrm{HLT}_{3} \times \mathrm{MEA}$} & $\mathrm{C} 1, \mathrm{C}{ }^{*}$ & $42.4 \pm 0.1$ & $64 \pm 9$ & $2.3 \pm 0.4$ \\
& $\mathrm{C} 2$ & $58.7 \pm 0.1$ & $87 \pm 11$ & $1.8 \pm 0.3$ \\
& $\mathrm{C} 2$ & $69.4 \pm 0.1$ & $67 \pm 14$ & $1.5 \pm 0.6$ \\
\hline
\end{tabular}

For the carbons of $\mathrm{BuNH}_{3}{ }^{+}$, as, when moving away from the nitrogen atom, both $T_{\mathrm{CH}}$ and $T_{1 \rho}(\mathrm{H})$ values grow up reflecting the increasing mobility. This is in-line with gradually decreasing the ${ }^{13} \mathrm{C}$ MAS NMR line width from $0.64 \mathrm{ppm}$ for C1 to $0.20 \mathrm{ppm}$ for C4 (Figure 7e). The carbon atom of the methyl group in the methanol derivative, which is covalently bounded to the lattice oxygen, exhibits the highest $T_{1 \rho}(\mathrm{H})$ value and the intermediate $T_{\mathrm{CH}}$ one, as compared to the methyl groups very mobile 
in $\mathrm{BuNH}_{3}{ }^{+}$and rather slow in $\mathrm{MeNH}_{3}{ }^{+}$. It means that the rotational motion of the $\mathrm{CH}_{3}$ group is relatively fast.

For the $\mathrm{HLT}_{3} \times$ MEA derivative, in which both intercalated cations and grated species coexist, $T_{\mathrm{CH}}$ and $T_{1 \rho}(\mathrm{H})$ values for both types of carbons are close, within the experiment error, to those for $\mathrm{C} 1$ of $\mathrm{BuNH}_{3}{ }^{+}$.

\section{Materials and Methods}

The layered perovskite $\mathrm{H}_{2} \mathrm{La}_{2} \mathrm{Ti}_{3} \mathrm{O}_{10} \cdot x \mathrm{H}_{2} \mathrm{O}\left(\mathrm{HLT}_{3}\right)$, where $x$ is an amount of intercalated water, was synthesized using $\mathrm{K}_{2} \mathrm{La}_{2} \mathrm{Ti}_{3} \mathrm{O}_{10}$ as a precursor. $\mathrm{K}_{2} \mathrm{La}_{2} \mathrm{Ti}_{3} \mathrm{O}_{10}$ was prepared by solid-phase synthesis, as described in Reference [50]. The protonation of $\mathrm{K}_{2} \mathrm{Ln}_{2} \mathrm{Ti}_{3} \mathrm{O}_{10}$ was carried out by the three-step procedure. Initially, the oxide was kept in moist air for $12 \mathrm{~h}$. Then, it was treated with an excess of water (200 mL per $1 \mathrm{~g}$ of the oxide) for $1 \mathrm{~h}$ and, hereafter, with an excess of $0.1-\mathrm{M} \mathrm{HNO}_{3}(200 \mathrm{~mL}$ per $1 \mathrm{~g}$ of the oxide) for $12 \mathrm{~h}$. After centrifugation, the product was dried under ambient pressure. The tetragonal lattice parameters of the protonated form obtained were found to be $a=3.809$ and $c=27.55 \AA$, which is consistent with the values in earlier reports $[4,76]$. The elimination of $\mathrm{K}^{+}$was confirmed by thermogravimetric analysis (TG) and, additionally, by energy-dispersive X-ray (EDX), which showed the lack of a potassium line. Calculations performed by the reported technique $[7,77]$ showed that no less than $95 \%$ of the alkali cations were replaced by protons.

Single-phase inorganic-organic hybrids were synthesized under optimal conditions found in the preliminary experiments (see Supplementary Materials). The methylamine derivative, $\mathrm{H}_{2} \mathrm{La}_{2} \mathrm{Ti}_{3} \mathrm{O}_{10} \times$ $\mathrm{MeNH}_{2}\left(\mathrm{HLT}_{3} \times \mathrm{MeNH}_{2}\right)$, was obtained by the reacting of $\mathrm{H}_{2} \mathrm{La}_{2} \mathrm{Ti}_{3} \mathrm{O}_{10}$ with an excess of $34 \%$ aqueous methylamine solution at $60{ }^{\circ} \mathrm{C}$ for 7 days under continuous stirring. Taking into account that large amine or alcohol molecules are difficult to introduce into $\mathrm{H}_{2} \mathrm{La}_{2} \mathrm{Ti}_{3} \mathrm{O}_{10}$, the hybrid structures containing $n$-butylamine and methanol were synthesized using the methylamine derivative as a precursor. To synthesize the $n$-butylamine derivative, $\mathrm{H}_{2} \mathrm{La}_{2} \mathrm{Ti}_{3} \mathrm{O}_{10} \times \mathrm{BuNH}_{2}\left(\mathrm{HLT}_{3} \times \mathrm{BuNH}_{2}\right)$, a mixture of the $\mathrm{HLT}_{3} \times \mathrm{MeNH}_{2}$ powder and an excess of $90 \% n$-butylamine aqueous solution was stirred at room temperature for 7 days. The adduct with methanol, $\mathrm{H}_{2} \mathrm{La}_{2} \mathrm{Ti}_{3} \mathrm{O}_{10} \times \mathrm{MeOH}\left(\mathrm{HLT}_{3} \times \mathrm{MeOH}\right)$, was obtained by a solvothermal reaction between the $\mathrm{HLT}_{3} \times \mathrm{BuNH}_{2}$ derivative and methanol at $100{ }^{\circ} \mathrm{C}$ for 10 days. The products were separated via centrifugation, washed with acetone, and dried in a desiccator. The monoethanolamine hybrid, $\mathrm{H}_{2} \mathrm{La}_{2} \mathrm{Ti}_{3} \mathrm{O}_{10} \times \mathrm{MEA}\left(\mathrm{HLT}_{3} \times \mathrm{MEA}\right)$, was prepared based on the $n$-butylamine derivative $\mathrm{HLT}_{3} \times \mathrm{BuNH}_{2}$ at $25{ }^{\circ} \mathrm{C}$ in $1 \mathrm{~d}$ using $90 \%$ monoethanolamine in water.

XRD patterns were obtained on the Rigaku Miniflex II diffractometer (Tokyo, Japan) $\left(\mathrm{CuK}_{\alpha}\right.$ radiation, angle range $2 \theta=3-60^{\circ}$, scanning rate $10^{\circ} / \mathrm{min}$, step $\left.0.01^{\circ}\right)$. The lattice parameters were calculated based on all the reflections observed using DiffracPlus Topas software (version 4.2). Raman spectra were obtained on the Bruker Senterra spectrometer (Karlsruhe, Germany) (spectral range $100-4000 \mathrm{~cm}^{-1}$, incident laser $488 \mathrm{~nm} 20 \mathrm{~mW}$, and spectrum accumulation time $10 \mathrm{~s}$ ). Fourier-transform infrared (IR) absorption spectra were recorded on the Shimadzu IRAffinity-1 spectrometer (Kyoto, Japan) (spectral range $400-4000 \mathrm{~cm}^{-1}$, tableting in $\mathrm{KBr}$ ). The amounts of carbon, hydrogen, and nitrogen in the hybrids were determined by the elemental $\mathrm{C}, \mathrm{H}, \mathrm{N}$ analysis on the Euro EA3028-HT analyzer (Redavalle, Italy). Simultaneous thermal analysis coupled with the mass spectrometric detection of gases evolved (STA-MS) was carried out on the Netzsch STA 409 CD-QMS 403/5 Skimmer system (Netzsch-Gruppe, Selb, Germany) using an air-containing (oxidative) atmosphere. Calculation of quantitative compositions of the inorganic-organic hybrids from STA-MS data was based on the direct proportionality of ion currents to the quantities of gases evolved and matching integrated ion currents with corresponding mass losses. The final compositions were established using results of the $\mathrm{C}, \mathrm{H}, \mathrm{N}$ analysis and STA-MS in total. The morphology of the samples was investigated by SEM on the Zeiss Merlin scanning electron microscope.

The solid-state ${ }^{1} \mathrm{H}-,{ }^{13} \mathrm{C}-$, and ${ }^{15} \mathrm{~N}-\mathrm{NMR}$ spectra were recorded on the Bruker Avance III 400WB spectrometer (Bruker Corporation, Billerica, MA, USA) using the MAS technique with a double-resonance 4 -mm probe. ${ }^{1} \mathrm{H}-\mathrm{NMR}$ spectra were recorded at $v_{\mathrm{rot}}=14 \mathrm{kHz}$ and the relaxation 
delay of $120 \mathrm{~s}$. To increase the intensity of ${ }^{13} \mathrm{C}$ and ${ }^{15} \mathrm{~N}$ signals, a cross-polarization $(\mathrm{CP})$ was applied. Static ${ }^{13} \mathrm{C}\left\{{ }^{1} \mathrm{H}\right\} \mathrm{CP}$ and ${ }^{13} \mathrm{C}\left\{{ }^{1} \mathrm{H}\right\} \mathrm{CP} / \mathrm{MAS}$ spectra $\left(v_{\text {rot }}=14 \mathrm{kHz}\right)$ were recorded at a relaxation delay of $5 \mathrm{~s}$ and a contact period $\tau_{\mathrm{cp}}=2 \mathrm{~ms}$ (for $\mathrm{HLT}_{3} \times \mathrm{MEA}, \tau_{\mathrm{cp}}=0.7 \mathrm{~ms}$ was used). ${ }^{13} \mathrm{C}\left\{{ }^{1} \mathrm{H}\right\} \mathrm{CP} / \mathrm{MAS}$ variable contact time (VCT) experiments were performed with $\tau_{\mathrm{cp}}$ varied between 10 and 10,000 $\mu \mathrm{s}$. ${ }^{15} \mathrm{~N}\left\{{ }^{1} \mathrm{H}\right\} \mathrm{CP} / \mathrm{MAS}$ spectra were obtained at $v_{\text {rot }}=12.5 \mathrm{kHz}$. Tetramethylsilane was used as an internal standard for ${ }^{1} \mathrm{H}$ and ${ }^{13} \mathrm{C}$, and ammonium chloride was used as an external standard for ${ }^{15} \mathrm{~N}$ $\left(\delta\left({ }^{15} \mathrm{NH}_{4} \mathrm{Cl}_{\text {cryst }}\right)=39.3 \mathrm{ppm}\right.$ relative to the liquid ammonia and can be converted into the nitromethane scale using the relations $\delta\left(\mathrm{CH}_{3}{ }^{15} \mathrm{NO}_{2}\right)=\delta\left({ }^{15} \mathrm{NH}_{4} \mathrm{Cl}\right)-338.1 \mathrm{ppm} \mathrm{[61].}{ }^{13} \mathrm{C}$ NMR spectra of crystalline $\mathrm{MeNH}_{2} \mathrm{HCl}, \mathrm{BuNH}_{2} \mathrm{HCl}$, and $\mathrm{Ti}\left(\mathrm{CH}_{3} \mathrm{O}\right)_{4}$ were recorded at $7 \mathrm{~T}$ on the Infinityplus spectrometer system (Agilent, Santa Clara, CA, USA) using a Chemagnetics-Varian 6-mm CP/MAS probe. These ${ }^{13} \mathrm{C}\left\{{ }^{1} \mathrm{H}\right\}$ $\mathrm{CP} / \mathrm{MAS}$ data were acquired using a relaxation delay of $5 \mathrm{~s}$ and $\nu_{\text {rot }}=5 \mathrm{kHz}$.

\section{Conclusions}

This study shows that the interlayer spaces of protonated perovskite-like titanates $\mathrm{H}_{2} \mathrm{Ln}_{2} \mathrm{Ti}_{3} \mathrm{O}_{10}$ $(\mathrm{Ln}=\mathrm{La}$ and $\mathrm{Nd})$ can be modified with the simplest representatives of amines (methylamine and $n$-butylamine), alcohols (methanol), and amino alcohols (monoethanolamine), giving inorganic-organic hybrids. The synthetic pathways of these hybrids were studied in a wide range of conditions using both standard laboratory techniques and solvothermal/solvothermal microwave methods. The optimal pathways of their preparation are summarized. Specifically, the methylamine hybrid, which was obtained by a one-step direct reaction, is a convenient precursor for the preparation of other types of hybrids. Thus, pure $n$-butylamine, methanolic, and monoethanolamine hybrids can be easily obtained using the methylamine hybrid as the precursor.

The ${ }^{1} \mathrm{H},{ }^{13} \mathrm{C}$, and ${ }^{15} \mathrm{~N}$ solid-state NMR spectroscopy and ${ }^{13} \mathrm{C}\left\{{ }^{1} \mathrm{H}\right\}$ VCT experiment, applied to study the bonding type of the obtained organic-inorganic hybrids and mobility of the organic components, unambiguously indicate that, in the methanolic hybrid, the organic residues are covalently bound to the inorganic matrix. In contrast, in the methylamine and $n$-butylamine hybrids, the organic molecules are intercalated into the inorganic matrix in a cationic form. The interlayer space of the monoethanolamine hybrid contains both the covalently bound and intercalated organic species.

These conclusions are supported by the vibrational spectroscopy data and thermal analysis. The thermal stability of the studied hybrids increases in a sequence: methylamine $/ n$-butylamine $\rightarrow$ monoethanolamine $\rightarrow$ methanol. The methanolic and monoethanolamine hybrids, due to their high thermal stability, can apparently be obtained in a hydrous form by thermal dehydration at $125-150{ }^{\circ} \mathrm{C}$.

Supplementary Materials: The following are available online: Figure S1: XRD patterns of (a) $\mathrm{HLT}_{3}$ and products of low-temperature reactions between $\mathrm{HLT}_{3}$ and methylamine under various conditions: (b) $1 \mathrm{~d}$ at $25^{\circ} \mathrm{C}$, (c) $1 \mathrm{~d}$ at $60^{\circ} \mathrm{C}$, (d) $7 \mathrm{~d}$ at $25^{\circ} \mathrm{C}$, (e) $7 \mathrm{~d}$ at $60^{\circ} \mathrm{C}$, (f) $14 \mathrm{~d}$ at $25^{\circ} \mathrm{C}$, and (g) $14 \mathrm{~d}$ at $60^{\circ} \mathrm{C}$. Figure S2: XRD patterns of (a) $\mathrm{HLT}_{3}$ and products of solvothermal and solvothermal microwave reactions between $\mathrm{HLT}_{3}$ and methylamine of various durations at $100{ }^{\circ} \mathrm{C}$ : (b) ST $1 \mathrm{~d}$, (c) ST $7 \mathrm{~d}$, (d) STMW $1 \mathrm{~h}$, (e) STMW $1 \mathrm{~d}$, and (f) STMW 3 d. Figure S3: XRD patterns of (a) $\mathrm{HLT}_{3}$ and products of low-temperature reactions between $\mathrm{HLT}_{3}$ and $n$-butylamine under various conditions: (b) $1 \mathrm{~d}$ at $25^{\circ} \mathrm{C}$, (c) $1 \mathrm{~d}$ at $60^{\circ} \mathrm{C}$, (d) $7 \mathrm{~d}$ at $25^{\circ} \mathrm{C}$, and (e) $7 \mathrm{~d}$ at $60^{\circ} \mathrm{C}$. Figure S4: XRD patterns of (a) $\mathrm{HLT}_{3}$ and products of solvothermal (ST) and solvothermal microwave (STMW) reactions between $\mathrm{HLT}_{3}$ and $n$-butylamine under various conditions: (b) ST $7 \mathrm{~d} 100{ }^{\circ} \mathrm{C}$, (c) STMW $1 \mathrm{~h} 100^{\circ} \mathrm{C}$, (d) STMW $1 \mathrm{~h} 150{ }^{\circ} \mathrm{C}$, and (e) STMW $1 \mathrm{~d} 100^{\circ} \mathrm{C}$. Figure S5: XRD patterns of (a) $\mathrm{HLT}_{3} \times \mathrm{MeNH}_{2}$ and products of reactions between $\mathrm{HLT}_{3} \times \mathrm{MeNH}_{2}$ and methanol: (b) $7 \mathrm{~d}$ at $60{ }^{\circ} \mathrm{C}$, (c) $5 \mathrm{~d}$ under solvothermal conditions at $100{ }^{\circ} \mathrm{C}$, and (d) $1 \mathrm{~d}$ under solvothermal microwave conditions at $100^{\circ} \mathrm{C}$. Figure S6: IR spectra of (a) $\mathrm{HLT}_{3}$, (b) $\mathrm{HLT}_{3} \times \mathrm{MeNH}_{2}$, (c) $\mathrm{HLT}_{3} \times \mathrm{BuNH}_{2}$, (d) $\mathrm{HLT}_{3} \times \mathrm{MeOH}_{\text {, }}$ and (e) $\mathrm{HLT}_{3} \times$ MEA. Figure S7: STA-MS data for methylamine hybrid $\mathrm{HLT}_{3} \times \mathrm{MeNH}_{2}$. Figure S8: STA-MS data for $n$-butylamine hybrid $\mathrm{HLT}_{3} \times \mathrm{BuNH}_{2}$. Figure S9: STA-MS data for methanolic hybrid $\mathrm{HLT}_{3} \times \mathrm{MeOH}_{\text {. }}$ Figure S10: STA-MS data for monoethanolamine hybrid $\mathrm{HLT}_{3} \times$ MEA. Table S1: Conditions of experiments on the optimization of the hybrid synthesis.

Author Contributions: Conceptualization, M.G.S. and O.I.S.; methodology, O.I.S., M.G.S., and I.G.S.; validation, M.G.S. and I.G.S.; investigation, O.I.S., I.P.L., S.A.K. and A.S.M.; writing—original draft preparation, M.G.S., S.A.K. and I.P.L.; writing-review and editing, M.G.S., O.I.S. and I.G.S.; supervision, O.I.S., M.G.S. and. I.A.Z.; project administration, I.A.Z.; and funding acquisition, I.A.Z. All authors have read and agreed to the published version of the manuscript. 
Funding: This study was performed under financial support by the Russian Science Foundation (project no. 19-13-00 184).

Acknowledgments: This study was performed using the facilities of the Magnetic Resonance Research Center, Center for X-ray Diffraction Studies, Center for Optical and Laser Research, Center for Thermogravimetric and Calorimetric Research, and Interdisciplinary Resource Center for Nanotechnology of the St. Petersburg State University.

Conflicts of Interest: No conflicts of interest were declared by the authors.

\section{References}

1. Yao, K.; Wang, X.; Xu, Y.X.; Li, F.; Zhou, L. Multilayered Perovskite Materials Based on Polymeric-Ammonium Cations for Stable Large-Area Solar Cell. Chem. Mater. 2016, 28, 3131-3138. [CrossRef]

2. Morell, J.; Chatterjee, S.; Klar, P.J.; Mauder, D.; Shenderovich, I.; Hoffmann, F.; Fröba, M. Synthesis and characterization of chiral benzylic ether-bridged periodic mesoporous organosilicas. Chem. Eur. J. 2008, 14, 5935-5940. [CrossRef] [PubMed]

3. Lerf, A. Storylines in intercalation chemistry. Dalt. Trans. 2014, 43, 10276-10291. [CrossRef] [PubMed]

4. Takata, T.; Furumi, Y.; Shinohara, K.; Tanaka, A.; Hara, M.; Kondo, J.N.; Domen, K. Photocatalytic decomposition of water on spontaneously hydrated layered perovskites. Chem. Mater. 1997, 9, 1063-1064. [CrossRef]

5. Rodionov, I.A.; Zvereva, I.A. Photocatalytic activity of layered perovskite-like oxides in practically valuable chemical reactions. Russ. Chem. Rev. 2016, 85, 248-279. [CrossRef]

6. Schaak, R.E.; Mallouk, T.E. Perovskites by design: A toolbox of solid-state reactions. Chem. Mater. 2002, 14, 1455-1471. [CrossRef]

7. Zvereva, I.A.; Silyukov, O.I.; Chislov, M.V. Ion-exchange reactions in the structure of perovskite-like layered oxides: I. Protonation of $\mathrm{NaNdTiO}_{4}$ complex oxide. Russ. J. Gen. Chem. 2011, 81, 1434-1441. [CrossRef]

8. Kurnosenko, S.A.; Silyukov, O.I.; Zvereva, I.A. Preparation of Porous Particles of Layered Perovskite-Like Titanate $\mathrm{HLaTiO}_{4}$. Glas. Phys. Chem. 2020, 46, 272-276. [CrossRef]

9. Silyukov, O.I.; Kurnosenko, S.A.; Zvereva, I.A. Intercalation of Methylamine into the Protonated Forms of Layered Perovskite-Like Oxides $\mathrm{HLnTiO}_{4}(\mathrm{Ln}=\mathrm{La}$ and Nd). Glas. Phys. Chem. 2018, 44, 428-432. [CrossRef]

10. Shelyapina, M.G.; Lushpinskaya, I.P.; Kurnosenko, S.A.; Silyukov, O.I.; Zvereva, I.A. Identification of intercalates and grafted organic derivatives of $\mathrm{H}_{2} \mathrm{La}_{2} \mathrm{Ti}_{3} \mathrm{O}_{10}$ by multinuclear NMR. Russ. J. Gen. Chem. 2020, 90, 760-761. [CrossRef]

11. Lee, W.-J.; Yeo, H.J.; Kim, D.-Y.; Paek, S.-M.; Kim, Y.-I. Exfoliation of Dion-Jacobson Layered Perovskite into Macromolecular Nanoplatelet. Bull. Korean Chem. Soc. 2013, 34, 2041-2043. [CrossRef]

12. Wang, T.H.; Henderson, C.N.; Draskovic, T.I.; Mallouk, T.E. Synthesis, exfoliation, and electronic/protonic conductivity of the dion-jacobson phase layer perovskite $\mathrm{HLa}_{2} \mathrm{TiTa}_{2} \mathrm{O}_{10}$. Chem. Mater. 2014, 26, 898-906. [CrossRef]

13. Han, Y.-S.; Park, I.; Choy, J.-H. Exfoliation of layered perovskite, $\mathrm{KCa}_{2} \mathrm{Nb}_{3} \mathrm{O}_{10}$, into colloidal nanosheets by a novel chemical process. J. Mater. Chem. 2001, 11, 1277-1282. [CrossRef]

14. Hojamberdiev, M.; Bekheet, M.F.; Zahedi, E.; Wagata, H.; Kamei, Y.; Yubuta, K.; Gurlo, A.; Matsushita, N.; Domen, K.; Teshima, K. New Dion-Jacobson Phase Three-Layer Perovskite $\mathrm{CsBa}_{2} \mathrm{Ta}_{3} \mathrm{O}_{10}$ and Its Conversion to Nitrided $\mathrm{Ba}_{2} \mathrm{Ta}_{3} \mathrm{O}_{10}$ Nanosheets via a Nitridation-Protonation-Intercalation-Exfoliation Route for Water Splitting. Cryst. Growth Des. 2016, 16, 2302-2308. [CrossRef]

15. Machida, M.; Miyazaki, K.; Matsushima, S.; Arai, M. Photocatalytic properties of layered perovskite tantalates, $\mathrm{MLnTa}_{2} \mathrm{O}_{7}(\mathrm{M}=\mathrm{Cs}, \mathrm{Rb}, \mathrm{Na}$, and $\mathrm{H} ; \mathrm{Ln}=\mathrm{La}, \mathrm{Pr}, \mathrm{Nd}$, and Sm). J. Mater. Chem. 2003, 13, 1433. [CrossRef]

16. Choi, J.; Zhang, X.; Wiley, J.B. Building alkali-metal-halide layers within a perovskite host by sequential intercalation: $\left(\mathrm{A}_{2} \mathrm{Cl}\right) \mathrm{LaNb}_{2} \mathrm{O}_{7}(\mathrm{~A}=\mathrm{Rb}, \mathrm{Cs})$. Inorg. Chem. 2009, 48, 4811-4816. [CrossRef]

17. Kawashima, K.; Hojamberdiev, M.; Wagata, H.; Yubuta, K.; Domen, K.; Teshima, K. Protonated Oxide, Nitrided, and Reoxidized $\mathrm{K}_{2} \mathrm{La}_{2} \mathrm{Ti}_{3} \mathrm{O}_{10}$ Crystals: Visible-Light-Induced Photocatalytic Water Oxidation and Fabrication of Their Nanosheets. ACS Sustain. Chem. Eng. 2017, 5, 232-240. [CrossRef]

18. Rodionov, I.A.; Silyukov, O.I.; Utkina, T.D.; Chislov, M.V.; Sokolova, Y.P.; Zvereva, I.A. Photocatalytic properties and hydration of perovskite-type layered titanates $\mathrm{A}_{2} \mathrm{Ln}_{2} \mathrm{Ti}_{3} \mathrm{O}_{10}(\mathrm{~A}=\mathrm{Li}, \mathrm{Na}, \mathrm{K} ; \mathrm{Ln}=\mathrm{La}, \mathrm{Nd})$. Russ. J. Gen. Chem. 2012, 82, 1191-1196. [CrossRef] 
19. Silyukov, O.I.; Abdulaeva, L.D.; Burovikhina, A.A.; Rodionov, I.A.; Zvereva, I.A. Phase transformations during $\mathrm{HLnTiO}_{4}(\mathrm{Ln}=\mathrm{La}, \mathrm{Nd})$ thermolysis and photocatalytic activity of obtained compounds. J. Solid State Chem. 2015, 226, 101-106. [CrossRef]

20. Rodionov, I.A.; Silyukov, O.I.; Zvereva, I.A. Study of photocatalytic activity of layered oxides: $\mathrm{NaNdTiO}_{4}$, $\mathrm{LiNdTiO}_{4}$, and $\mathrm{HNdTiO}_{4}$ titanates. Russ. J. Gen. Chem. 2012, 82, 635-638. [CrossRef]

21. Rodionov, I.A.; Maksimova, E.A.; Pozhidaev, A.Y.; Kurnosenko, S.A.; Silyukov, O.I.; Zvereva, I.A. Layered Titanate $\mathrm{H}_{2} \mathrm{Nd}_{2} \mathrm{Ti}_{3} \mathrm{O}_{10}$ Intercalated with n-Butylamine: A New Highly Efficient Hybrid Photocatalyst for Hydrogen Production from Aqueous Solutions of Alcohols. Front. Chem. 2019, 7, 1-13. [CrossRef] [PubMed]

22. Voytovich, V.V.; Kurnosenko, S.A.; Silyukov, O.I.; Rodionov, I.A.; Minich, I.A.; Zvereva, I.A. Study of n-alkylamine Intercalated Layered Perovskite-Like Niobates $\mathrm{HCa}_{2} \mathrm{Nb}_{3} \mathrm{O}_{10}$ as Photocatalysts for Hydrogen Production From an Aqueous Solution of Methanol. Front. Chem. 2020, 8, 300. [CrossRef] [PubMed]

23. Fang, M.; Kim, C.H.; Mallouk, T.E. Dielectric Properties of the Lamellar Niobates and Titanoniobates $\mathrm{AM}_{2} \mathrm{Nb}_{3} \mathrm{O}_{10}$ and $\mathrm{ATiNbO}_{5}(\mathrm{~A}=\mathrm{H}, \mathrm{K}, \mathrm{M}=\mathrm{Ca}, \mathrm{Pb})$, and Their Condensation Products $\mathrm{Ca}_{4} \mathrm{Nb}_{6} \mathrm{O}_{19}$ and $\mathrm{Ti}_{2} \mathrm{Nb}_{2} \mathrm{O}_{9}$. Chem. Mater. 1999, 11, 1519-1525. [CrossRef]

24. Takayanagi, S.; Ogawa, S. Superconducting properties of Layered Perovskite $\mathrm{KCa}_{2} \mathrm{Nb}_{3} \mathrm{O}_{10}$ and $\mathrm{KLaNb}_{2} \mathrm{O}_{7}$. Solid State Ion. 1997, 103, 215-217.

25. Toda, K.; Honma, T.; Sato, M. Unusual concentration quenching of europium luminescence in new layered perovskite compound, $\mathrm{RbLa}_{1-\mathrm{x}} \mathrm{Eu}_{\mathrm{x}} \mathrm{Ta}_{2} \mathrm{O}_{7}$. J. Lumin. 1997, 71, 71-75. [CrossRef]

26. Sugahara, Y. Chemical processes employing inorganic layered compounds for inorganic and inorganic-organic hybrid materials. J. Ceram. Soc. Jpn. 2014, 122, 523-529. [CrossRef]

27. Ranmohotti, K.G.S.; Josepha, E.; Choi, J.; Zhang, J.; Wiley, J.B. Topochemical manipulation of perovskites: Low-temperature reaction strategies for directing structure and properties. Adv. Mater. 2011, 23, 442-460. [CrossRef]

28. Tahara, S.; Ichikawa, T.; Kajiwara, G.; Sugahara, Y. Reactivity of the Ruddlesden-Popper Phase $\mathrm{H}_{2} \mathrm{La}_{2} \mathrm{Ti}_{3} \mathrm{O}_{10}$ with Organic Compounds: Intercalation and Grafting Reactions. Chem. Mater. 2007, 19, 2352-2358. [CrossRef]

29. Tahara, S.; Sugahara, Y. Interlayer Surface Modification of the Protonated Triple-Layered Perovskite $\mathrm{HCa}_{2} \mathrm{Nb}_{3} \mathrm{O}_{10} \cdot \mathrm{xH}_{2} \mathrm{O}$ with $n$-Alcohols. Langmuir 2003, 19, 9473-9478. [CrossRef]

30. Tahara, S.; Takeda, Y.; Sugahara, Y. Preparation of Organic-Inorganic Hybrids Possessing Nanosheets with Perovskite-Related Structures via Exfoliation during a Sol-Gel Process. Chem. Mater. 2005, 17, 6198-6204. [CrossRef]

31. Wang, C.; Tang, K.; Wang, D.; Liu, Z.; Wang, L.; Zhu, Y.; Qian, Y. A new carbon intercalated compound of Dion-Jacobson phase HLaNb ${ }_{2} \mathrm{O}_{7}$. J. Mater. Chem. 2012, 22, 11086. [CrossRef]

32. Kimura, N.; Kato, Y.; Suzuki, R.; Shimada, A.; Tahara, S.; Nakato, T.; Matsukawa, K.; Mutin, P.H.; Sugahara, Y. Single- and Double-Layered Organically Modified Nanosheets by Selective Interlayer Grafting and Exfoliation of Layered Potassium Hexaniobate. Langmuir 2014, 30, 1169-1175. [CrossRef] [PubMed]

33. Corriu, R.J.P.; Leclercq, D. Recent Developments of Molecular Chemistry for Sol-Gel Processes. Angew. Chem. 1996, 35, 1420-1436. [CrossRef]

34. Sanchez, C.; Soler-Illia, G.J.D.A.A.; Ribot, F.; Lalot, T.; Mayer, C.R.; Cabuil, V. Designed hybrid organic-inorganic nanocomposites from functional nanobuilding blocks. Chem. Mater. 2001, 13, 3061-3083. [CrossRef]

35. Faustini, M.; Nicole, L.; Ruiz-Hitzky, E.; Sanchez, C. History of organic-inorganic hybrid materials: Prehistory, art, science, and advanced applications. Adv. Funct. Mater. 2018, 28, 1-30. [CrossRef]

36. Bin, D.; Huo, W.; Yuan, Y.; Huang, J.; Liu, Y.; Zhang, Y.; Dong, F.; Wang, Y.; Xia, Y. Organic-inorganic-induced polymer intercalation into layered composites for aqueous zinc-ion battery. Chem 2020, 6, 968-984. [CrossRef]

37. Wang, Y.; Nikolopoulou, M.; Delahaye, E.; Leuvrey, C.; Leroux, F.; Rabu, P.; Rogez, G. Microwave-assisted functionalization of the Aurivillius phase $\mathrm{Bi}_{2} \mathrm{SrTa}_{2} \mathrm{O}_{9}$ : Diol grafting and amine insertion vs. alcohol grafting. Chem. Sci. 2018, 9, 7104-7114. [CrossRef]

38. Wang, Y.; Delahaye, E.; Leuvrey, C.; Leroux, F.; Rabu, P.; Rogez, G. Post-synthesis modification of the aurivillius phase $\mathrm{Bi}_{2} \mathrm{SrTa}_{2} \mathrm{O}_{9}$ via in situ microwave-assisted “click reaction". Inorg. Chem. 2016, 55, 9790-9797. [CrossRef] 
39. Idota, N.; Fukuda, S.; Tsukahara, T.; Sugahara, Y. Preparation of thermoresponsive nanosheets exhibiting phase transitions in water via surface modification of layered perovskite nanosheets with poly(N-isopropylacrylamide) (PNIPAAm). Chem. Lett. 2015, 44, 203-205. [CrossRef]

40. Sato, S.; Shintani, K.; Idota, N.; Nishino, T.; Sugahara, Y. Effect of the graft density of cellulose diacetate-modified layered perovskite nanosheets on mechanical properties of the transparent organic-inorganic hybrids bearing covalent bonds at the interface. Cellulose 2017, 24, 5463-5473. [CrossRef]

41. Asai, Y.; Ariake, Y.; Saito, H.; Idota, N.; Matsukawa, K.; Nishino, T.; Sugahara, Y. Layered perovskite nanosheets bearing fluoroalkoxy groups: Their preparation and application in epoxy-based hybrids. RSC Adv. 2014, 4, 26932-26939. [CrossRef]

42. Byeon, S.; Kileung, P.; Park, K. Structure and Ionic Conductivity of $\mathrm{NaLnTiO}_{4}$, Comparison with Those of $\mathrm{Na}_{2} \mathrm{Ln}_{2} \mathrm{Ti}_{3} \mathrm{O}_{10}(\mathrm{Ln}=\mathrm{La}, \mathrm{Nd}, \mathrm{Sm}$, and Gd). J. Solid State Chem. 1996, 121, 430-436. [CrossRef]

43. Richard, M.; Brohan, L.; Tournoux, M. Synthesis, Characterization, and Acid Exchange of the Layered Perovskites $\mathrm{A}_{2} \mathrm{Nd}_{2} \mathrm{Ti}_{3} \mathrm{O}_{10}(\mathrm{~A}-\mathrm{Na}, \mathrm{K})$. J. Solid State Chem. 1994, 112, 345-354. [CrossRef]

44. Rodionov, I.A.; Sokolova, I.P.; Silyukov, O.I.; Burovikhina, A.A.; Fateev, S.A.; Zvereva, I.A. Protonation and Photocatalytic Activity of the $\mathrm{Rb}_{2} \mathrm{La}_{2} \mathrm{Ti}_{3} \mathrm{O}_{10}$ Layered Oxide in the Reaction of Hydrogen Production. Int. J. Photoenergy 2017, 2017, 1-8. [CrossRef]

45. Tong, Z.; Zhang, G.; Takagi, S.; Shimada, T.; Tachibana, H.; Inoue, H. Preparation and Characterization of a Transparent Thin Film of the Layered Perovskite, $\mathrm{K}_{2} \mathrm{La}_{2} \mathrm{Ti}_{3} \mathrm{O}_{10}$, Intercalated with an Ionic Porphyrin. Chem. Lett. 2005, 34, 632-633. [CrossRef]

46. Akbarian-Tefaghi, S.; Wiley, J.B. Microwave-assisted routes for rapid and efficient modification of layered perovskites. Dalt. Trans. 2018, 47, 2917-2924. [CrossRef]

47. Chizhik, V.I.; Chernyshev, Y.S.; Donets, A.V.; Frolov, V.V.; Komolkin, A.V.; Shelyapina, M.G. Magnetic Resonance and Its Applications; Springer International Publishing: Cham, Switzerland, 2014; ISBN 9783319052984.

48. Kharkov, B.B.; Corkery, R.W.; Dvinskikh, S.V. Phase transitions and chain dynamics of surfactants intercalated into the galleries of naturally occurring clay mineral magadiite. Langmuir 2014, 30, 7859-7866. [CrossRef]

49. Krylova, E.A.; Shelyapina, M.G.; Nowak, P.; Harańczyk, H.; Chislov, M.; Zvereva, I.A.; Privalov, A.F.; Becker, M.; Vogel, M.; Petranovskii, V. Mobility of water molecules in sodium- and copper-exchanged mordenites: Thermal analysis and ${ }^{1} \mathrm{H}$ NMR. Microporous Mesoporous Mater. 2018, 265, 132-142. [CrossRef]

50. Shelyapina, M.G.; Nefedov, D.Y.; Kostromin, A.V.; Silyukov, O.I.; Zvereva, I.A. Proton mobility in Ruddlesden-Popper phase $\mathrm{H}_{2} \mathrm{La}_{2} \mathrm{Ti}_{3} \mathrm{O}_{10}$ studied by ${ }^{1} \mathrm{H}-\mathrm{NMR}$. Ceram. Int. 2019, 45, 5788-5795. [CrossRef]

51. Kharkov, B.B.; Dvinskikh, S. Chain dynamics of surfactants in mesoporous silica. Phys. Chem. Chem. Phys. 2013, 42, 18620-18626. [CrossRef]

52. Khimyak, Y.Z.; Klinowski, J. Solid-state NMR studies of the organic template in mesostructured aluminophosphates. Phys. Chem. Chem. Phys. 2001, 3, 616-626. [CrossRef]

53. Shelyapina, M.G.; Yocupicio-Gaxiola, R.I.; Zhelezniak, I.V.; Chislov, M.V.; Antúnez-García, J.; Murrieta-Rico, F.N.; Galván, D.H.; Petranovskii, V.; Fuentes-Moyado, S. Local structures of two-dimensional zeolites-Mordenite and ZSM-5—Probed by multinuclear NMR. Molecules 2020, 25, 4678. [CrossRef] [PubMed]

54. Kurnosenko, S.A.; Silyukov, O.I.; Mazur, A.S.; Zvereva, I.A. Synthesis and thermal stability of new inorganic-organic perovskite-like hybrids based on layered titanates $\mathrm{HLnTiO}_{4}(\mathrm{Ln}=\mathrm{La}, \mathrm{Nd})$. Ceram. Int. 2019, 46, 5058-5068. [CrossRef]

55. Byeon, S.; Nam, H. Neutron Diffraction and FT-Raman Study of Ion-Exchangeable Layered Titanates and Niobates. Chem. Mater. 2000, 12, 1771-1778. [CrossRef]

56. Nozaki, R.; Kondo, J.N.; Hirose, C.; Domen, K.; Wada, A. Vibrational Study of Layered Perovskites $\mathrm{M}_{2} \mathrm{La}_{2} \mathrm{Ti}_{3} \mathrm{O}_{10}(\mathrm{M}=\mathrm{Li}, \mathrm{Na}, \mathrm{K}, \mathrm{Rb})$ : Raman Spectra and Normal Mode Analysis. J. Phys. Chem. B 2001, 105, 7950-7953. [CrossRef]

57. Torres-Barthelemy, V.; Pérez-Hernández, N.; Shenderovich, I.G.; Tolstoy, P.M.; Denisov, G.S.; Limbach, H.-H. NMR-detected host-guest proton exchange as a tool to explore surface/volume ratios and fluid filling of internal and external spaces of porous solids containing surface $\mathrm{OH}$ groups. J. Phys. Chem. C 2020, 124, 22082-22095. [CrossRef] 
58. Kong, S.; Borissova, A.O.; Lesnichin, S.B.; Hartl, M.; Daemen, L.L.; Eckert, J.; Antipin, M.Y.; Shenderovich, I.G. Geometry and spectral properties of the protonated homodimer of pyridine in the liquid and solid states. A combined NMR, X-ray diffraction and inelastic neutron scattering study. J. Phys. Chem. A 2011, 115, 8041-8048. [CrossRef]

59. Grünberg, B.; Emmler, T.; Gedat, E.; Shenderovich, I.; Findenegg, G.H.; Limbach, H.; Buntkowsky, G. Hydrogen bonding of water confined in mesoporous silica MCM-41 and SBA-15 studied by ${ }^{1} \mathrm{H}$ solid-state NMR. Chem. Eur. J. 2004, 10, 5689-5696. [CrossRef]

60. Shenderovich, I.G. For whom a puddle is the sea? Adsorption of organic guests on hydrated MCM-41 silica. Langmuir 2020, 36, 11383-11392. [CrossRef]

61. Lorente, P.; Shenderovich, I.G.; Golubev, N.S.; Denisov, G.S.; Buntkowsky, G.; Limbach, H.H. ${ }^{1} \mathrm{H} /{ }^{15} \mathrm{~N}$ NMR chemical shielding, dipolar ${ }^{15} \mathrm{~N},{ }^{2} \mathrm{H}$ coupling and hydrogen bond geometry correlations in a novel series of hydrogen-bonded acid-base complexes of collidine with carboxylic acids. Magn. Reson. Chem. 2001, 39, 18-29. [CrossRef]

62. Cattaneo, A.S.A.S.; Ferrara, C.; Marculescu, A.M.A.M.; Giannici, F.; Martorana, A.; Mustarelli, P.; Tealdi, C. Solid-state NMR characterization of the structure and thermal stability of hybrid organic-inorganic compounds based on a $\mathrm{HLaNb}_{2} \mathrm{O}_{7}$ Dion-Jacobson layered perovskite. Phys. Chem. Chem. Phys. 2016, 18, 21903-21912. [CrossRef] [PubMed]

63. Crocker, M.; Herold, R.H.M.; Wilson, A.E.; Mackay, M.; Emeis, C.A.; Hoogendoorn, A.M. ${ }^{1}$ H NMR spectroscopy of titania: Chemical shift assignments for hydroxy groups in crystalline and amorphous forms of $\mathrm{TiO}_{2}$. J. Chem. Soc. Faraday Trans. 1996, 92, 2791-2798. [CrossRef]

64. Yang, L.; Feng, N.; Wang, Q.; Chu, Y.; Xu, J.; Deng, F. Surface water loading on titanium dioxide modulates photocatalytic water splitting. Cell Rep. Phys. Sci. 2020, 1, 100013. [CrossRef]

65. Jeantelot, G.; Ould-Chikh, S.; Sofack-Kreutzer, J.; Abou-Hamad, E.; Anjum, D.H.; Lopatin, S.; Harb, M.; Cavallo, L.; Basset, J.M. Morphology control of anatase $\mathrm{TiO}_{2}$ for well-defined surface chemistry. Phys. Chem. Chem. Phys. 2018, 20, 14362-14373. [CrossRef]

66. Tupikina, E.Y.; Bodensteiner, M.; Tolstoy, P.M.; Denisov, G.S.; Shenderovich, I.G. P=O Moiety as an ambidextrous hydrogen bond acceptor. J. Phys. Chem. C 2018, 122, 1711-1720. [CrossRef]

67. Gutiérrez-Ortega, J.A.; Gómez-Salazar, S.; Shenderovich, I.G.; Manríquez-González, R. Efficiency and lead uptake mechanism of a phosphonate functionalized mesoporous silica through $\mathrm{P} / \mathrm{Pb}$ association ratio. Mater. Chem. Phys. 2020, 239, 122037. [CrossRef]

68. Gurinov, A.A.; Rozhkova, Y.A.; Zukal, A.; Čejka, J.; Shenderovich, I.G. Mutable Lewis and Brønsted acidity of aluminated SBA-15 as revealed by NMR of adsorbed pyridine- ${ }^{15}$ N. Langmuir 2011, 27, 12115-12123. [CrossRef]

69. Witanowski, M.; Stefaniak, L.; Szymański, S.; Januszewski, H. External neat nitromethane scale for nitrogen chemical shifts. J. Magn. Reson. 1977, 28, 217-226. [CrossRef]

70. Bishop, G.R.; Valente, E.J.; Whitehead, T.L.; Brown, K.L.; Hicks, R.P.; Davidson, V.L. Direct detection by ${ }^{15} \mathrm{~N}$ NMR of the tryptophan tryptophylquinone aminoquinol reaction intermediate of methylamine dehydrogenase. J. Am. Chem. Soc. 1996, 118, 12868-12869. [CrossRef]

71. Banert, K.; Lehmann, J.; Quast, H.; Meichsner, G.; Regnat, D.; Seiferling, B. ${ }^{15}$ N-NMR spectra, tautomerism and diastereomerism of 4,5-dihydro-1H-1,2,3-triazoles. J. Chem. Soc. Perkin Trans. 2002, 2, 126-134. [CrossRef]

72. Duthaler, R.O.; Roberts, J.D. Steric and electronic effects on ${ }^{15} \mathrm{~N}$ chemical shifts of saturated aliphatic amines and their hydrochlorides. J. Am. Chem. Soc. 1978, 100, 3889-3895. [CrossRef]

73. Liu, H.; Li, M.; Luo, X.; Liang, Z.; Idem, R.; Tontiwachwuthikul, P. Investigation mechanism of DEA as an activator on aqueous MEA solution for postcombustion $\mathrm{CO}_{2}$ capture. AIChE J. 2018, 64, 2515-2525. [CrossRef]

74. Birnie, D.P.; Bendzko, N.J. ${ }^{1} \mathrm{H}$ - and ${ }^{13} \mathrm{C}-\mathrm{NMR}$ observation of the reaction of acetic acid with titanium isopropoxide. Mater. Chem. Phys. 1999, 59, 26-35. [CrossRef]

75. Voelkel, R. High-resolution solid-state ${ }^{13}$ C-NMR spectroscopy of polymers. Angew. Chem. Int. Ed. Engl. 1988, 27, 1468-1483. [CrossRef] 
76. Rodionov, I.A.; Fateev, S.A.; Zvereva, I.A. Synthesis of a New Layered $\mathrm{Rb}_{2} \mathrm{Nd}_{2} \mathrm{Ti}_{3} \mathrm{O}_{10}$ Oxide, Its Hydration and Protonation. Glas. Phys. Chem. 2017, 43, 593-596. [CrossRef]

77. Silyukov, O.; Chislov, M.; Burovikhina, A.; Utkina, T.; Zvereva, I. Thermogravimetry study of ion exchange and hydration in layered oxide materials. J. Therm. Anal. Calorim. 2012, 110, 187-192. [CrossRef]

Sample Availability: Samples of the compounds are available from the authors upon request.

Publisher's Note: MDPI stays neutral with regard to jurisdictional claims in published maps and institutional affiliations.

(C) 2020 by the authors. Licensee MDPI, Basel, Switzerland. This article is an open access article distributed under the terms and conditions of the Creative Commons Attribution (CC BY) license (http://creativecommons.org/licenses/by/4.0/). 